\title{
THE
}

\section{Consumer financial education and risky financial asset holding in China}

Ting Zhu

Jing Jian Xiao

University of Rhode Island, xiao@uri.edu

Follow this and additional works at: https://digitalcommons.uri.edu/hdf_facpubs

The University of Rhode Island Faculty have made this article openly available.

Please let us know how Open Access to this research benefits you.

This is a pre-publication author manuscript of the final, published article.

Terms of Use

This article is made available under the terms and conditions applicable towards Open Access Policy Articles, as set forth in our Terms of Use.

\section{Citation/Publisher Attribution}

Zhu, T., \& Xiao, J. J. (2020). Consumer financial education and risky financial asset holding in China. International Journal of Consumer Studies. Early View. https://doi.org/10.1111/ijcs.12643

Available at: https://doi.org/10.1111/ijcs.12643

This Article is brought to you for free and open access by the Human Development and Family Science at DigitalCommons@URI. It has been accepted for inclusion in Human Development and Family Science Faculty Publications by an authorized administrator of DigitalCommons@URI. For more information, please contact digitalcommons-group@uri.edu. 
Zhu, T., \& Xiao, J. J. (2020). Consumer financial education and risky financial asset holding in China. International Journal of Consumer Studies. Early View. https://doi.org/10.1111/ijcs.12643

\title{
Consumer Financial Education and Risky Financial Asset Holding in China
}

Ting Zhu, Jing Jian Xiao

\begin{abstract}
Risky financial asset holding is arguably a desirable financial behavior that contributes to consumer financial wellbeing. However, studies about associations between consumer financial education and risky financial asset holding in China remain limited. To fill this gap, using data from the 2015 China Household Finance Survey, this study examined the association between financial education and risky financial asset holdings and explored its mediators. Results from Probit regressions showed that financial education was positively associated with the household risky financial asset holding. Further analyses based on the mediating model found that financial literacy, economic and financial information search, and risk tolerance were mediating factors in the association between financial education and risky financial asset holding. The results have policy implications for improving consumer financial education and financial market participation.
\end{abstract}

Key words: financial education, financial literacy, financial market participation, risky financial assets, risk tolerance

\section{Introduction}

Household financial asset holding is an important topic in household finance (Campbell, 2006; Xiao \& Tao, 2020) and consumer financial literacy research (Goyal \& Kumar, 2020). Risky financial assets refer to financial assets that possess financial risk, such as stocks, bonds, and mutual funds. Holding risky financial assets may not be appropriate for all consumers especially those with low income and low wealth but in general, this is considered a desirable financial behavior. According to the Merton model 
(Merton, 1969), all consumers who have adequate resources to invest, independently of their wealth and of their preferences towards risk, should participate in all risky assets markets and should invest in the market portfolio to take advantage of the equity premium (Guiso \& Sodini, 2013). Holding risky financial assets is considered a desirable strategy in effective asset allocations (Cardek \& Wilkins, 2009) and an indicator of efficient investment behavior (Campbell, 2016).

With the establishment and continuous improvement of China's market economy, especially since the launch of the Shanghai Stock Exchange and the Shenzhen Stock Exchange, the Chinese financial market has been developed at a rapid pace. Chinese households have the opportunity to accumulate and increase their wealth through a variety of investment channels such as holding risky financial assets. According to the China Household Finance Survey (CHFS) conducted in 2011, 2013, 2015 and 2017, the proportions for holding risky financial assets were about $12.21 \%, 11.95 \%, 17.48 \%$ and $16.34 \%$, respectively ${ }^{1}$. Moreover, Chinese households primarily participate in the financial market by holding stock and wealth management product in recent years with proportions about $7.05 \%$ and $10.73 \%$ in the 2017 CHFS. Therefore, holding risky financial assets becomes common for Chinese households. However, the risk and return always coexist in any investment, and high risk corresponds high return. In addition, with the development of the financial market, financial assets are becoming more diverse and complex. On the one hand, consumers are eager to maintain and increase wealth through holding risky financial assets. On the other hand, confronted with complex financial assets and lack of financial knowledge, consumers make mistakes in investment decisions (Campbell, 2016).

The level of financial literacy among Chinese consumers is low compared with developed countries (Liao et al., 2017). Especially with the rapid development of digital finance, many consumers with low

\footnotetext{
${ }^{1}$ The statistical data were calculated by the authors based on the CHFS datasets for 2011, 2013, 2015 and 2017.
} 
financial literacy are confronted with many illegal financial products and financial frauds, which leads to considerable financial losses to them. Financial literacy is needed for them to make rational decisions and receive positive investment returns. In recent years, the Chinese government took actions regularly aimed at improving consumer financial knowledge, such as Financial Literacy Month. Consumers could receive financial education through various channels offered in the workplace, schools, universities, financial institutions, and nonprofit organizations. Thence, it is of great importance to investigate the association between consumer financial education and risky financial asset holding in China.

Research demonstrates that consumer financial education is associated with consumers financial wellbeing (Xiao \& Porto, 2017) in which financial wellbeing means a state of being financially healthy, happy, and free from worry (Joo, 2008). Consumer financial education refers to programs or intervention processes by which an individual improves their understanding of financial products and develops the skills and confidence (Organization for Economic Co-operation and Development, 2005). In this study, financial literacy and financial knowledge are used as synonyms that refer to basic knowledge relevant to financial products and markets. Financial education may raise the level of financial literacy (Xiao \& O’Neill, 2016) and motivate desirable financial behaviors, which could enhance consumer financial wellbeing (Atkinson et al., 2006; Huhmann \& McQuitty, 2009; Kaiser \& Menkhoff, 2017, 2019; Lusardi \& Mitchell, 2014; Mouna \& Jarboui, 2015; Reyers, 2019; Tajurahim et al., 2020; Utkarsh et al., 2020; Xiao et al. 2020).

Consumer risky financial asset holding is also considered to be one of important financial behaviors. Previous studies have noted that holding risky financial assets is influenced by individual and household characteristics, such as age, wealth, education (Alessie, Hochguertel \& Van Soest, 2002; Berkowitz \& Qiu, 2006; Grinblatt, Keloharju \& Linnainmaa, 2011; Guiso \& Jappelli, 2000), social network (Brown 
et al., 2008; Hong et al., 2004) and trust (Georgarakos and Pasini, 2011). To our knowledge, no previous research has looked at the relationship between financial education and household risky financial asset holding, and explored the mediating roles of financial literacy, economic and financial information search, and risk tolerance. To fill this gap, we examined the association between financial education and risky financial asset holding using data from the 2015 China Household Finance Survey (CHFS). We also examined the mediating roles of consumer financial literacy, economic and financial information search, and risk tolerance in the association between financial education and risky financial asset holding. In addition, we explored heterogeneous associations in terms of different household characteristics. Finally, we used the 2013 CHFS, different definitions of risky financial asset holding and different types of risky financial assets to conduct robust tests.

Financial market participation refers to investor's general participation by holding and investing in specific financial products in a financial market (Chen et al., 2020). Participation in financial markets can be divided in two ways according to different risk level of assets: holding risk-free assets and risky assets. In this paper, we focus on financial market participation by holding risky financial assets.

It is important to explore the relationship between financial education and risky financial asset holding, which would explore whether financial education promotes participation in financial market. On the one hand, risky financial assets have higher return than other risk-free assets. Consumers who have received financial education could invest risky financial assets and allocate assets properly to gain high returns. On the other hand, high returns always accompany high risks in financial markets. Consumers who have received financial education should understand the risk and be more careful in holding risky financial assets. Furthermore, it is also important to examine specific channels leading to financial risky asset holding to better understand this consumer behavior. 
This paper makes the following contributions: First, it enriches the literature of financial education by examining the relationship between financial education and risky financial asset holding. Previous research did not focus on the relationship between financial education and risky financial asset holding directly or indirectly. Many studies examined the relationship between financial literacy and financial market participation (Arrondel, Debbich \& Savignac, 2012; Christelis, Jappelli \& Padula, 2010; Li, Li $\&$ Wei, 2020). However, we estimate the relationship between financial education, a factor never used in previous research, and risky financial asset holding, and find the positive association between them. Second, we explore possible mediating variables between financial education and risky financial asset holding, such as financial literacy, economic and financial information search, and risk tolerance. We estimate both direct and indirect associations between financial education and risky financial asset holding.

The remainder of this paper is arranged as follows. Section 2 reviews relevant existing studies and proposes hypotheses. Section 3 describes the dataset, variables, and analytic models. Results and discussion about benchmark regression, intermediate mechanisms and robustness checks are presented in Section 4. Section 5 includes limitations and future directions. Finally, Section 6 presents the conclusion and policy implications.

\section{Previous Research and Hypotheses}

\subsection{The Conceptual Framework}

A theoretical model on demand for financial literacy is proposed by Lusardi, Michaud and Mitchell (2017). In this model, financial knowledge has large cumulative effects over the life cycle and enables individuals to better allocate lifetime resources. Financial knowledge permits consumers to use 
sophisticated financial products to raise higher returns. It can be socially optimal to raise financial knowledge for everyone early in life, such as by mandating financial education in high school, gaining knowledge from parents and so on. Delavande, Rohwedder and Willis (2008) presented a simple twoperiod model of consumers portfolio allocation across safe bond and risky stock with the financial knowledge as human capital. They found that it is optimal for individuals to invest in financial knowledge. This could help them identify better-performing assets and save on the cost of hiring financial advisers. Further, it could increase the expected return from their portfolio of risky assets without incurring additional risk. As a formal financial socialization process, financial education plays a prominent role in obtaining financial knowledge (Fan \& Chatterjee, 2019). Therefore, from a theoretical point of view, these predictions suggest that investment in financial knowledge, in other words receiving financial education, plays a very important role in increasing consumers ability to manage their money and financially perform better. Previous studies also show financial education contributes to financial literacy, behavior, capability, and wellbeing (Kaiser \& Menkhoff, 2017, 2019; Lusardi \& Mitchell, 2014; Xiao \& O’Neill, 2016; Xiao \& Porto, 2017). Based on the literature discussed above, we propose the conceptual framework shown in Figure 1 that is similar to Xiao and Porto (2017)'s conceptual model of "educationcapability-wellbeing." In this conceptual framework, financial education is directly associated with risky financial asset holding, which is regarded as a desirable financial behavior leading to financial wellbeing (Chen et al., 2020). What's more, as consumer financial ability indicators, financial literacy, information search, and risk tolerance are mediators between financial education and risky financial asset holding.

This conceptual framework is used to guide the development of hypotheses for this study.

\subsection{Financial Education and Risky Financial Asset Holding}

Benefits of financial education for consumers are documented in previous research (Asarta, Hill \& 
Meszaros 2014; Brown et al., 2016; Clark, Lusardi \& Mitchell, 2017; Kaiser \& Menkhoff, 2019; Kim \&

Xiao, 2020; Lusardi, 2019; Miller et al., 2015; Urban et al. 2020). Recent meta-analysis verified the positive effects of financial education on financial literacy and behaviors (Kaiser \& Menkhoff, 2017, 2019; Miller et al., 2015). Kaiser and Menkhoff (2019) examined the literature on school financial education programs for children and youth which contain 37 total independent (quasi-) experimental studies and found sizeable impacts of financial education treatment on financial knowledge and behaviors. Empirical studies also show evidence on positive effects of financial education on financial literacy, financial behaviors, financial capability, and financial wellbeing. Urban et al. (2020) found that rigorous financial education programs, coupled with teacher training and high school financial education requirements, are correlated with fewer defaults and higher credit scores among young adults in the US. After investigating the impact of statewide financial education reforms which affect large populations of high school students, Brown et al., (2016) found that financial education decreases reliance on nonstudent debt and improves repayment behavior. Financial education increases financial literacy (Lusardi \& Mitchell, 2007; Wagner, 2019; Xiao \& Porto, 2017) and encourages desirable financial behaviors among students (Lyons, 2008; Peng et al., 2007) and employees (Bayer, Bernheim \& Scholz, 2009; Bernheim \& Garrett, 2003). In addition, financial education is very important for saving decisions and retirement planning (Chen, Zhang \& Ma, 2020; Lusardi,2008; Lusardi \& Mitchell, 2007; Skimmyhorn,2012). However, the effects of financial education are controversial. Some empirical or review research suggest that financial education has limited effects on financial outcomes (Collins \& O’Rourke, 2010; Fernandes, Lynch \& Netemeyer, 2014; Mandell \& Klein, 2009; Willis, 2011). However, these studies did not deny the importance of financial education, and believed that financial education can be improved to become more effective. 
Previous research mainly focuses on one type of financial education, such as high school (Bernheim, Garrett \& Maki, 2001; Brown et al., 2014; Brown et al., 2016; McCormick, 2009; Walstad, Rebeck \& MacDonald, 2010), college (Lyons, 2004; Lyons, 2008; Xiao, Serido \& Shim, 2012; Xiao et al., 2014) or among adults (Bayer, Bernheim \& Scholz, 2009; Bernheim \& Garrett, 2003; Clark, Lusardi \& Mitchell, 2014; Joo \& Grable, 2005; Kim, Garman \& Quach, 2005), but few studies have looked at all three (Wagner, 2019). Xiao and O'Neill (2016) estimated the effects of high school, college, and adult financial education simultaneously on financial capability. They found that receiving financial education from high school, college, and the workplace are positively associated with financial capability. In this paper, we also use financial education which refers to any financial education received from high school, college, the workplace, or any other sources, and link it with an important economic outcome: risky financial asset holding.

According to the Merton model (Merton, 1969), all investors, independent of their wealth and of their preferences towards risk, should participate in all risky assets markets and should invest in the market portfolio to take advantage of the equity premium (Guiso \& Sodini, 2013). Theoretical and empirical research on household financial asset holding has been the focus of research in the past half century (Campbell, 2006). Many previous research studies focus on household participation in the financial market, especially in the stock market (Poterba \& Samwick, 2003; Vissing-Jorgensen, 2002). Household risky financial asset holding is affected by many factors. The most important one is the risk of financial assets. Different assets have different risk levels which have positive associations with returns (Markowitz, 1952). Other factors which influence household risky financial asset holding include age (Alessie, Hochguertel \& Van Soest, 2002; Guiso \& Jappelli, 2000), wealth (Guiso \& Jappelli, 2000), education (Guiso \& Jappelli, 2000), health (Atella et al., 2012; Berkowitz \& Qiu, 2006), intelligence 
quotient (Grinblatt, Keloharju \& Linnainmaa, 2011), trust (Georgarakos \& Pasini, 2011) and so on. Previous studies also have addressed the role of financial market participation by holding risky financial assets in consumers subjective wellbeing (Frijters et al., 2015; Murgea \& Reisz, 2013). Chen et al. (2020) investigated the relationships between holding risky financial assets and subject wellbeing by using the China Household Financial Survey (CHFS), and the results indicate that holding risky assets contribute negatively to subjective wellbeing. However, Murgea and Reisz (2013) found positive relationships between subjective wellbeing and stock market participation in the USA. In this paper, we focus on household participation in financial markets by observing whether households hold risky financial assets or not, other than the share of risky financial assets held.

Based on the above discussion, financial education would increase financial knowledge. More knowledgeable consumers are more likely to perform desirable financial behaviors. Holding risky financial assets is considered such a behavior that helps increase wealth. Then, we propose the following hypothesis:

H1. Financial education is positively associated with risky financial asset holding.

\subsection{Financial Literacy as the Mediator}

Besides the direct associations between financial education and risky financial asset holding, we also propose three hypotheses about mediating factors in the association between financial education and risk financial asset holding.

First, financial literacy has been found to affect both saving and investment behavior and debt management and borrowing practices (Hamid \& Loke, 2020; Hastings \& Mitchell, 2020; Lusardi \& Tufano, 2009, 2015; Lusardi \& Mitchell, 2014). Financial literacy mainly focuses on the understanding 
of economic and financial concepts and knowledge about financial instruments (Xiao, 2015). Consumers with higher financial literacy have better performance in financial behavior, such as lower probability of bank loan overdue (Fedorova, Nekhaenko \& Dovzhenko, 2015), lower credit card and mortgage costs (Huston 2012), better financial planning (Arrondel, Debbich \& Savignac, 2013), and a better chance of receiving a positive investment return (Chu et al., 2017; Jiang et al., 2020). As for risky financial asset holding, Liao et al. (2017) found that consumers with higher financial literacy are more likely to hold risky financial assets than those with lower financial literacy in China. By studying the portfolio allocation decisions of Australian households, Cardak and Wilkins (2009) found that financial awareness and knowledge play important roles in determining risky asset holdings. Several studies also found that those who are more financially literate are more likely to participate in financial markets, invest in stocks (Arrondel, Debbich \& Savignac, 2012; Christelis, Jappelli \& Padula, 2010; Cupák et al., 2020; Li, Li \& Wei, 2020; Rooij, Lusardi \& Alessie 2011; Yoong, 2011) and have better diversification and more frequent stock trading (Graham, Harvey \& Huang, 2009). For example, using a panel dataset covering a representative sample of the Dutch population, Rooij, Lusardi and Alessie (2011) found that financial literacy has effects on financial decision-making, especially on stock investment.

Based on those previous studies, we infer that there are positive associations between both financial education and financial literacy, and between financial literacy and risky financial asset holding in Chinese households. That is, financial literacy is the mediator between financial education and risky financial asset holding. Therefore, we propose the following hypothesis:

H2. Financial education is positively associated with financial literacy, and financial literacy in turn is positively associated with risky financial asset holding.

\subsection{Information Search as the Mediator}


Second, we also assume that with financial education, consumers pay more attention to the economic or financial information in their daily life. Consumers usually make financial decisions based on limited knowledge and incomplete information. Improving the access to information would facilitate more effective investment decisions ( $\mathrm{Li}, 2014)$. Previous studies have emphasized the importance of acquiring information on financial market participation from social networks (Chiteji \& Stafford, 1999; Guiso, Sapienza \& Zingales, 2004; Hong, Kubik \& Stein, 2004; Li, 2014) and the Internet (Bogan, 2008; Liang \& Guo, 2015; Markus \& Alexander, 2013). Therefore, it is important for consumers to capture related information actively. After knowing about the economic situation and the financial markets, consumers are more likely to invest in risky financial assets. Hence, we propose the following hypothesis:

H3. Financial education positively contributes to economic and financial information search, and economic and financial information search in turn is positively associated with the risky financial asset holding.

\subsection{Risk Tolerance as the Mediator}

Finally, financial education has been found to increase consumers financial risk tolerance (Ryack, 2011), and risk attitude which affects the choice of financial assets. High risk aversion is associated with a lesser likelihood of making investments in the stock market (Dimmock \& Kouwenberg, 2010; Lim, Soutar \& Lee, 2013). Barasinska, Schfer and Stephan (2012) examined the effect of personal risk attitude on financial portfolios among German households, and found that there is a significant effect of risk attitude on holding risky assets. The higher level of risk aversion, the higher proportion of risk-free assets households prefer to hold. In addition, the more educated investors are, the more they value diversification and hold risky assets (Mitchell \& Moore, 1998). Several studies also found there are 
positive effects of financial literacy on the level of risk tolerance (Bajo, Barbi \& Sandri, 2015; Mishra, 2018). Based on this correlation, financial education may increase financial confidence which may lead to higher levels of risk tolerance. Thus, we propose the following hypothesis:

H4. Financial education is positively associated with risk tolerance, and risk tolerance in turn is positively associated with risky financial asset holding.

\section{Method}

\subsection{Dataset}

Data used in this study was from the 2015 China Household Finance Survey (CHFS) conducted by China Household Finance Survey and Research Center at the Southwestern University of Finance and Economics in Chengdu, China. This survey collected information from 37,289 households in 29 provinces, autonomous regions, and municipalities, 351 counties, and 1,396 communities. The survey is a nationally representative sample and has been carried out every two years from 2011. Up until now, the data was available to the public in four waves: 2011, 2013, 2015 and 2017. The survey in 2011 only collected data from 8,438 households, and the 2013 survey collected from 28,141 households. The 2015 survey increased the number of samples to 37,289 and the 2017 survey contains 40,011 households. In each survey, it includes relevant household information, including household assets, liabilities and credit constraints, income, consumption, social security and insurance, demographic characteristics, employment, payment habits and so on (Gan et al., 2013). For more details about the dataset, the reader should refer to Gan et al. (2013) or CHFS official website: https://chfs.swufe.edu.cn/. Because the 2017 survey doesn’t ask households about their financial education, we used the 2015 survey in our main analyses and the 2013 survey for robustness tests. 


\subsection{Variables}

CHFS chooses the family member who has the best knowledge of the family's financial situation as the respondent in each household. Therefore, this paper used the respondent as the representative of each household.

Financial education. This is a dummy variable in CHFS2015. Based on the survey question "Have you ever taken an economic or financial class?" if the respondent has received economic or financial education, then $f i n e d u=1$, otherwise, fined $u=0$.

Risky financial asset holding. In CFHS, the risky financial assets include stocks, funds, wealth management products (a popular investment product issued through banks), derivatives, bonds, nonRMB assets and precious metal. The CFHS has detailed information about whether the household holds each of these assets or not. In this paper, the variable regarding holding risky financial assets is generated whether households have any types of risky financial assets or not. The dummy variable risfinass_h=1 if the household holds risky financial assets, otherwise, risfinass_ $h=0$.

Financial literacy. Lusardi and Mitchell (2008, 2011a, 2011b) have designed three questions to measure basic financial knowledge, including questions about the interest rate calculation, understanding of inflation, and judgment of financial risk. These questions are used in numerous surveys in the United States as well as other countries. There are similar questions in CHFS2015 which are also used in many published studies (Feng et al., 2019). The specific questions are shown in the Appendix. Financial literacy was measured according to the number of correct answers. Therefore, finliter ranges from 0 to 3 . And the higher the finliter, the higher the financial literacy.

Economic and financial information search. In CHFS, respondents were asked "What is your degree of concern for economic and financial information?" Responses range from 1 (Not at all) to 5 
(Extremely concerned).

Risk tolerance. The risk attitude was measured using a 5-point scale in CHFS. The respondents were asked "Which of the choices below do you want to invest in most if you have adequate money?" The answers were "Unwilling to carry any risk", "Project with slight risk and return", "Project with average risk and return", "Project with slightly high-risk and slightly high-return" and "Project with highrisk and high-return", with corresponding scales ranging from 1 to 5 . The higher the scale, the higher level of risk tolerance.

Control variables. Control variables at individual, household, and regional level were used following previous research. Several demographic variables were included such as age, education years, political status, marriage, gender, the registered residence type and if working in a financial sector at an individual level (respondent's situation); and income and household size at household level. At the regional level, the following control variable were used: whether the household is in a rural region or not and whether it is in the eastern or western region of China (middle region is the reference category). The specific definitions of variables are shown in Table 1.

\subsection{Data Analysis}

The basic model is to estimate the relationship between financial education and risky financial asset holding. Because the main dependent variable, risky financial asset holding ( risfinass_h), is a binary variable, the Probit model was used to estimate the relationship between financial education and risky financial asset holding. Suppose that for household $i$, the decision risfinass $h_{i}$ to hold risky financial assets can only assume two values, 0 or 1 . Its value is determined by the latent variable risfinass_ $h_{i}^{*}$. When risfinass_ $h_{i}^{*}>0$, risfinass_ $h=1$; when risfinass_ $h_{i}^{*}=0$, risfinass_ $h=0$. Therefore, the following Probit regression was used with assuming $\varepsilon$ obeys standard normal distribution: 
$\operatorname{Pr}\left(\right.$ risfinass $_{h_{i}}=1 \mid$ fined $\left._{i}, \boldsymbol{X}\right)=\operatorname{Pr}\left(\right.$ risfinass $_{h_{i}^{*}}^{*}>0 \mid$ fined $\left._{i}, \boldsymbol{X}\right)=\Phi\left(\beta_{0}+\beta_{1}\right.$ fined $\left._{i}+\boldsymbol{\gamma} \boldsymbol{X}+\delta_{p}\right)$

where $\mathbf{X}$ represent the control variables including individual level, household level and region level. In control variables, income is transformed to logarithms. And $\delta_{p}$ represents province fixed effect and $\varepsilon$ is the error term. Equation one is used to test $\mathrm{H} 1$.

After estimating the relationships between financial education and risky financial asset holding, this study explored the intermediate mechanisms. The following three mediators were considered in this study: financial literacy, economic and financial information search, and risk tolerance. To test $\mathrm{H} 2, \mathrm{H} 3$, and $\mathrm{H} 4$, the mediating model was used as follows (Baron \& Kenny, 1986), where the first formula is the same as formula (1):

$$
\begin{gathered}
\text { Mediator }=\beta_{0}+\beta_{1} \text { fined }_{i}+\boldsymbol{\gamma} \boldsymbol{X}+\delta_{p}+\varepsilon \\
\operatorname{Pr}\left(\text { risfinass }_{h_{i}}=1 \mid \text { fined }_{i}, \boldsymbol{X}\right)=\Phi\left(\beta_{0}+\beta_{1} \text { fined }_{i}+\beta_{2} \text { Mediator }+\boldsymbol{\gamma} \boldsymbol{X}+\delta_{p}\right)
\end{gathered}
$$

where the Mediators include three variables, finliter, concern_ecofin and Risk_tolerance. According to previous hypotheses, the coefficients of $\beta_{1}$ in equation (2) and $\beta_{2}$ in equation (3) are expected both positive and significant if the mediators are finliter, concern_ecofin or Risk_tolerance. As mentioned in Mustillo et al. (2018), a significance test for the difference in magnitude between coefficients in the above mediating model should be run to determine whether mediation has occurred. Changes in statistical significance may not be significant (Gelman \& Stern, 2006). Therefore, the Sobel (1986) test was used to see if the reduction in coefficient is statistically significant and verify the mediating effects.

Furthermore, because the coefficients in the Probit model does not show the marginal effects of each variable on dependent variable directly, this study calculated the average marginal effect of each variable in each Probit regression for the convenience of discussing and interpreting the results. The 
average marginal effect of each variable is calculated by following equation four based on Greene (2018), taking finedu as the example:

$$
\mathrm{AME}=\frac{1}{n} \sum_{i=1}^{n} f\left(\text { fined }^{\prime}{ }^{\prime} \hat{\beta}_{1}\right) \hat{\beta}_{1}
$$

where $n$ represent the number of observations in our sample, and $\hat{\beta}_{1}$ is the estimated value of $\beta_{1}$.

Finally, heterogeneity analysis was estimated in terms of several household characteristics and robustness tests for the basic results and the intermediate mechanisms were conducted by using data from the 2013 China Household Finance Survey, using different definition of risky financial asset holding and different types of risky financial assets. STATA 15 was used for data analyses.

\section{Results and Discussions}

\subsection{Descriptive Statistics of the Sample}

Descriptive statistics of the sample are shown in Table 2. During the data cleansing process, following $\mathrm{Li}, \mathrm{Wu}$ and Xiao (2020), we eliminated observations with missing values of used variables, and only kept households in which the respondent's age is 18 or older. 32,554 observations remained in the data analyses which accounts for about $87.3 \%$ of the initial whole sample. As seen in Table 2, about $17.7 \%$ of households hold risky financial assets and $7.3 \%$ of household respondents have received economic or financial education. The level of consumers financial literacy is very low with the mean number of correct answers at 0.985 , consistent with the results in Liao et al. (2017). In addition, the results show that the level of economic and financial information search is also very low with a mean level of about 2.2. The average score for risk tolerance is about 1.9 which means most consumers in China are risk averse.

Table 3 presents the details of financial asset holdings. $95.7 \%$ of households hold financial assets 
and only $17.7 \%$ of households hold risky financial assets which means financial market participation by holding risky assets is low. In households that hold financial assets, the most popular financial asset is demand deposit which has the lowest risk. Moreover, the most popular risky financial asset is stock, followed by wealth management product.

In the 2015 CHFS, the respondents were asked "Have you ever taken an economic or financial class?" We did not know from which channel the respondent received financial education (in school, the workplace, community, or internet). Therefore, we did a simple cross tabulation between the education years and financial education (see its row percentage in Table 4). This table shows that financial education and education years are correlated with one other. Higher education levels have higher probabilities of receiving financial education. However, we cannot conclude that the financial education is from school. In China, financial education is not compulsory at each education level. Some people in economics, business, or related majors may receive financial education at colleges or universities. Others who are interested in economics and finance may receive related knowledge from various sources such as financial education programs offered by financial institutions, government agencies, or nonprofit organizations.

We also did the Pearson Chi-square test between financial education and risky financial asset holding. The results are significant which means financial education and risky financial asset holding are not mutually independent. This suggests consumers receiving financial education are more likely to hold risky financial assets than those not receiving financial education ( $52 \%$ vs. $\left.15 \%, \chi^{2}=2.1 \mathrm{e}+03, \mathrm{p}<0.001\right)$. Table A1 shows the correlation matrix among all variables we used. The correlation coefficients between any two independent variables are small which means a weak correlation and will not lead to multicollinearity problems in regression. 


\subsection{Benchmark Regression Results}

The Probit regression was used to estimate the relationship between financial education and risky financial asset holding and the results are shown in Table 5. Column one only has one independent variable: financial education. Column two adds control variables and column three adds both control variables and province fixed effects. Column four is the average marginal effects of each independent variables on risky financial asset holding. Because the coefficients in the Probit models do not show marginal effects, we presented marginal effects in column four calculated by equation four. The coefficients of financial education in all four columns are positive and significant. Consumers receiving financial education experience an $8.5 \%$ increase in the probability of holding risky financial assets compared to those without financial education. According to the results, financial education is positively associated with the probability of risky financial asset holding, supporting H1.

As for the control variables, most of the correlations are with expected signs. Table 5 also shows that consumers are more likely to hold risky financial assets if they are female, young, with a high level of education, a member of the Communist Party of China, having a non-agriculture registered residence, married, working in a financial sector, with a high income and small household size, and living in an urban, and/or east region of China.

\subsection{Mechanisms Results}

This section presents results of possible mediating factors between financial education and risky financial asset holding. We considered three mediators: financial literacy, economic and financial information search, and risk tolerance. Equations 1-3 were used to identify the mediating effects.

$\mathrm{H} 2$ states that financial education is positively associated with financial literacy, and financial 
literacy in turn is positively associated with risky financial asset holding. Table 6 presents the results. Column one of Table 6 is the result of equation one which is the same with column three in Table 5 . Column two is its marginal effects results. Column three of Table 6 is the result of equation two and shows that financial education would increase consumers' financial literacy significantly. In addition, in column four and column five, the coefficients of financial literacy are significant and the signs of coefficients are the same with the coefficients of financial education. This means that financial literacy would increase the probability of holding risky financial assets, which is consistent with Liao et al. (2017). After adding financial literacy as an independent variable in columns four and five, the coefficient of the association between financial education and risky financial asset holding probability is still significant and the marginal effect is lower than the coefficients in column two. This means that financial literacy has a certain mediating effect, supporting $\mathrm{H} 2$.

Table 7 shows the results for which economic and financial information search is used as the mediating variable in the association between financial education and risky financial asset holding. Columns one and two of Table 7 is the result of equations one and four. This is the same with columns three and four in Table 5. In column three, the coefficient of financial education is positive and significant, suggesting that financial education would increase the consumers' attention to economic and financial information. The results in columns four and five show that the coefficient and marginal effect of economic and financial information search are both positive and significant. The marginal effect of financial education is significant and its value is smaller than that in column two. Thus, economic and financial information search is a mediating variable in the association between financial education and risky financial asset holding, supporting H3. It is very important for investors to know information about the economic situation and the financial market situation before they make investment choices ( $\mathrm{Li}, 2014)$. 
The knowledge about the economy and market will help consumers make the right choices and allocate their assets into promising products. Nowadays, consumers have multiple ways to obtain the information about the economy and financial markets, such as traditional media (TV, newspaper), apps related to finance and economics, and websites through the Internet and mobile phone. Financial education will help consumers to understand professional vocabularies and theories, which could also encourage consumers to economic and financial information search. More economic and financial information search will let them know more about the markets and invest the risky financial assets in proper time and ways.

Risk tolerance is an important factor that affects risky financial asset holding (Barasinska, Schfer $\&$ Stephan, 2012). Table 8 presents the results for which risk tolerance is the mediator. Columns one and two are the results of equation one which are the same with columns three and four in Table 5. Firstly, in column three, results suggest that financial education may increase consumers' risk tolerance. Then, in columns four and five, the coefficient and marginal effect of risk tolerance and financial education are both positive and significant. The value of marginal effect of financial education is smaller than that in baseline results, which means that risk tolerance is a mediating variable in the association between financial education and risky financial asset holding, supporting H4. After receiving financial education, consumers will know more about the economy and financial markets, and understand the risks of various types of financial assets. Then, an individual's risk tolerance in financial markets will change (Ryack, 2011) and lead to diversified risky financial asset holding choices.

In addition, we conducted Sobel (1986) test for our mediating analyses. The results are shown in Table 9. The coefficients of Sobel in Table 9 are significant which means all three variables are mediators between financial education and probability of risky financial asset holding. The results also show that 
the mediating effects of financial literacy, economic and financial information search, and risk tolerance account for $7.2 \%, 26.6 \%$ and $15.0 \%$ of total effects of financial education on the probability of risky financial asset holding, respectively.

\subsection{Heterogeneity Results}

This section reports the heterogeneity of the relationships between financial education and risky financial asset holding in terms of several household characteristics: household respondents' education, political status, and age. For households with different characteristics, financial education may play different roles in risky financial asset holding. The regression results are shown in Table 10.

Columns one and two show the heterogeneous associations of financial education by different education years. The interaction coefficients between financial education and education year are significant and the signs are negative which are different from the coefficient and marginal effect of financial education. The results show that for highly educated consumers, the association between financial education and risky financial asset holding are smaller. A possible explanation for this result is that highly educated consumers are more likely to hold risky financial assets (Campbell, 2006), because education reduces the fixed costs of participating by making it easier for them to understand the market's risk-reward tradeoff and to deal with the mechanics of setting up an account (Hong, Kubik \& Stein, 2004). Individuals may hold risky financial assets even if they didn't receive financial education. However, for consumers with lower education levels, they receive financial education more likely for investment purposes and the marginal benefits of financial education for them are larger than those with higher education levels.

We also explore the heterogeneous associations on different political statuses in columns three and four. The coefficient and marginal effect of the interaction terms are significant and negative. This means 
that for members of the Communist Party, financial education has a smaller association with the probability to hold risky financial assets than their counterparts. Party membership is a promising indicator of associational social capital in China (Knight \& Yueh, 2008). Therefore, the findings could be explained in that most party members are highly educated and have abundant social network resources and have basic financial knowledge and market information without receiving financial education. The marginal benefits of financial education for non-party members are larger than their counterparts.

Additionally, we explored the heterogeneous associations on age in columns five and six. The coefficient and marginal effect of the interaction term are significant and positive. This means that for the older household respondents, financial education has higher associations with the probability to hold risky financial assets than their counterparts. For young people, they are curious about something new and can accept and understand them quickly, and can actively participate in the financial market. Our cross tabulation between age and risky financial asset holding in Table A2 show that there is higher probability of holding risky financial assets in younger consumers. Although the Chinese financial market developed with rapid space, the financial market participation of Chinese consumers by holding risky assets is still low, with only about $16.34 \%$ households in $2017^{2}$. Financial markets and related financial knowledge are new things for older people which they know little about and don't invest without financial education. In addition, according to the life cycle hypothesis, older consumers accumulated their income for retirement and they have greater wealth than younger consumers. This means the marginal benefits of financial education for them is larger, which leads to a higher association between financial education and risky financial asset holding than younger consumers.

\subsection{Robustness Checks}

\footnotetext{
${ }^{2}$ The statistical data were calculated by the authors based on the CHFS datasets for 2017 .
} 


\subsubsection{Using the 2013 CHFS}

In our main results, we used the 2015 China Household Financial Survey. Because 2017 CHFS has no survey question about financial education, we used the 2013 CHFS for robust tests. The 2013 survey collected from 28,141 households in 29 provinces, autonomous regions, and municipalities, 267 counties, and 1,048 communities. We used the 2013 CHFS to do the basic Probit regression (equation one) and the mediating variable regression (equations one to three). The results are shown in the Appendix (Table A3). Columns 1 and 2 are the baseline results. The coefficient and marginal effect of financial education are significant and the signs are the same as those in Table 5. In addition, we tested the robustness of mediating regression in Section 4.3. Columns three to five are the regressions with financial literacy as the mediator. The results show that financial literacy has a certain mediating effect through which financial education is associated with the probability of risky financial asset holding. Columns six to eight and columns nine to eleven test the mediating effects of economic and financial information search, and risk tolerance, respectively. The results show that economic and financial information search and risk tolerance have certain mediating effects between financial education and the probability of risky financial asset holding. The above results are consistent with our previous findings which means that our previous results are robust.

\subsubsection{Excluding Government Bonds}

In our sample, bonds include state treasury bonds, local government bonds, financial bonds, corporate bonds and other bonds. Government bonds, including state treasury bonds and local government bonds, are regarded as risk-free assets in China (Liao et al., 2017). To check whether our results are contaminated by government bonds, we redefine risky financial asset holding by excluding holding government bonds, and reexamine the associations between financial education and risky 
financial asset holding by using the 2015 CHFS. The results are shown in Column one and two of Appendix (Table A4). We also show a strong and significant associations between financial education and risky financial asset holding.

\subsubsection{Different Types of Risky Financial Assets}

Considering that different types of risky financial assets have different risk, we estimate the heterogeneous responses of different type of risky financial assets. Column three to ten of Table A4 consider four main types: stock, funds, wealth management products and bonds which exclude government bonds. Financial education has positive associations with all these four types of risky financial assets, especially with higher associations with stock market participation.

\section{Limitations and Directions for Future Research}

Several limitations exist in this study. First, we only used a simple conceptual framework but didn't propose a formal theoretical model that describes the association between financial education and risky financial asset holding and its mechanisms. Second, only survey data was used. Third, this paper only considered whether or not consumers hold risky financial assets. Fourth, we only considered three mediators between financial education and risky financial asset holding. Fifth, financial education was measured by only a single item.

Following the approach used by Paul and Mas (2020), we propose three directions for future research in terms of theories, constructs, and methods. First, a more formal theory on the association between financial education and risky financial asset holding and its mechanisms could be developed. Relevant theories in economics, finance, psychology, and education could be considered for theory building. Existing theories such as the life cycle consumption theory (Modigliani \& Brumberg, 1954), 
theory of planned behavior (Ajzen,1991), the financial literacy model proposed by Lusardi, Michaud and Mitchell (2017), portfolio theory (Markowitz, 1952) and the model of consumption and portfolio choice proposed by Merton (1969) could be integrated in some way. For example, based on the results of this study, besides financial literacy, information search and risk tolerance are also important mediating factors between the link of financial education and risky asset holding. These factors could be formally treated in an economic utility model similar to the financial literacy model proposed by Lusardi, Michaud and Mitchell (2017). Theoretical literature reviews on the topic of financial education and investing behavior could also be conducted towards theory building. Second, constructs related to this study could be measured more accurately. In this study, financial education is measured with only one item due to the limitation of the dataset. In future research, different datasets could be used with more indicators of financial education attributes such as the offering organizations, class times, class contents, course quality, etc. For the risky financial asset variable, more refined risk levels of various financial assets should be considered and integrated into the data analyses in future research. Third, in terms of methodology, this study is based on survey data. To more accurately capture the causal effect of financial education and investing behavior, data from different sources could be used such as data from experiments and financial service transactions. In addition, more mediators could be included to explore the comprehensive benefits of financial education on consumer financial capability and wellbeing (Xiao \& Porto, 2017) by using different datasets that have other relevant variables.

\section{Conclusion}

This study has used the 2015 China Household Financial Survey to examine the association between financial education and risky financial asset holding. The results suggest that financial education may 
increase the probability to invest in risky financial assets, especially for consumers being at lower education levels, non-party members, and older. The mediating model results suggest that financial literacy, economic and financial information search, and risk tolerance are mediating variables between financial education and risky financial asset holding. In sum, financial education may increase household risky financial asset holding through increasing financial literacy, economic and financial information search, and risk tolerance. Therefore, this study contributes to the existing literature on holding risky financial assets, an important behavior for consumer participation in financial markets. This study also provides new evidence showing the importance of financial education on financial behavior, and identifies three mediators between financial education and risky financial asset holding.

Relevant government agencies should promote financial knowledge to the public and encourage active consumer participation in financial markets. Consumer educators could use these findings to educate consumers on the importance of receiving financial education, improving their financial literacy to make rational and appropriate investment decisions. Moreover, financial service institutions should provide adequate information about the risky financial assets, such as risk, previous return and so on, which could make consumers more aware of risky financial assets and participate in financial markets more efficiently. Consumers should actively participate in financial education by taking formal or informal courses from schools or other sources, keep track of important economic and financial news, and know more about risks of various investment products. Consumers could also take advice from financial advisors to match their investment decisions with their risk tolerance. 
Appendix: Financial literacy questions in 2015 China Household Financial Survey.

1. Given a $4 \%$ interest rate, how much would you have in total after 1 year if you have 100 yuan deposited?

(1) Under 104; (2) 104; (3) Over 104; (4) Cannot figure out;

2. With an interest rate of $5 \%$ and an inflation rate of $3 \%$, the staff you buy with the money you have saved in the bank for 1 year is

(1) More than last year; (2) The same as last year; (3) Less than last year; (4) Cannot figure out;

3. Which one do you think is more risky, stock or fund?

(1) Stock; (2) Fund; (3) Haven't heard about stock;

(4) Haven't heard about fund; (5) Neither of them has been heard about 


\section{Reference}

Ajzen, I. (1991). The theory of planned behavior. Organizational Behavior and Human Decision Processes, 50, 179-211.

Alessie, R., Hochguertel, S., \& Van Soest, A. (2002). Household portfolios in the Netherlands. In L. Guiso, M. Haliassos, \& T. Jappelli (Eds.), Household Portfolios (pp.341-388). MIT Press.

Arrondel, L., Debbich, M., \& Savignac, F. (2012). Stockholding and financial literacy in the French population. International Journal of Social Sciences and Humanity Studies, 4(2), 285-294.

Arrondel, L, Debbich M, \& Savignac F. (2013). Financial literacy and financial planning in France. Numeracy, 6(2), article No. 8. http://dx.doi.org/10.5038/1936-4660.6.2.8

Asarta, C. J., Hill, A. T., \& Meszaros, B. T. (2014). The features and effectiveness of the keys to financial success curriculum. International Review of Economics Education, 16, 39-50.

Atella, V., Brunetti, M., \& Maestas, N. (2012). Household portfolio choices, health status and health care systems: A cross-country analysis based on SHARE. Journal of Banking and Finance, 36(5), 13201335 .

Atkinson, A., McKay, S., Kempson, E. \& Collard, S. (2006). Levels of financial capability in the UK: Results of a baseline survey. Financial Services Authority, London.

Bajo, E., Barbi, M., \& Sandri, S. (2015). Financial literacy, households' investment behavior, and risk propensity. Journal of Financial Management, Markets and Institutions, 3(1), 157-174.

Barasinska, N., Schfer, D, \& Stephan, A. (2012). Individual risk attitudes and the composition of financial portfolios: Evidence from German household portfolios. Quarterly Review of Economics and Finance, 52(1), 1-14.

Baron, R.M., \& Kenny, D.A. (1986). The moderator-mediator variable distinction in social psychological research: conceptual, strategic, and statistical considerations. Journal of Personality and Social Psychology, 51 (6), 1173-1182.

Bayer, P.J., Bernheim, B.D., \& Scholz, J.K. (2009). The effects of financial education in the workplace: Evidence from a survey of employers. Economic Inquiry, 47(4), 605-624.

Berkowitz, M. K., \& Qiu J. (2006). A further look at household portfolio choice and health status. Journal of Banking and Finance, 30(4), 1201-1217.

Bernheim, B. D., \& Garrett, D. M. (2003). The effects of financial education in the workplace: Evidence from a survey of households. Journal of Public Economics, 87(7), 1487-1519.

Bernheim, B. D., Garrett, D. M., \& Maki, D. M. (2001). Education and saving: The long-term effects of high school financial curriculum mandates. Journal of Public Economics, 80(3), 435-465.

Bogan, V. (2008). Stock market participation and the internet. Journal of Financial and Quantitative Analysis,43, 191-211.

Brown, A. M., Collins, J. M., Schmeiser, M. D., \& Urban, C. (2014). State mandated financial education and the credit behavior of young adults. Divisions of Research \& Statistics and Monetary Affairs Federal Reserve Board, Washington, DC, Finance and Economics Discussion Series, (2014-68).

Brown, J. R., Ivković, Z., Smith, P. A., \& Weisbenner, S. (2008). Neighbors matter: Causal community effects and stock market participation. Journal of Finance, 63(3), 1509-1531.

Brown, M., Grigsby, J., Van Der Klaauw, W., Wen, J., \& Zafar, B. (2016). Financial education and the debt behavior of the young. Review of Financial Studies, 29(9), 2490-2522.

Campbell, J. Y., (2006). Household finance. Journal of Finance, 61, 1553-1604.

Campbell, J. Y. (2016). Restoring rational choice: The challenge of consumer financial regulation. American Economic Review, 106(5), 1-30. 
Cardak, B. A., \& Wilkins, R. (2009). The determinants of household risky asset holdings: Australian evidence on background risk and other factors. Journal of Banking and Finance, 33(5), 850-860.

Chen, F., Hsu, C. L., Lin, A. J., \& Li, H. (2020). Holding risky financial assets and subjective wellbeing: Empirical evidence from China. North American Journal of Economics and Finance, 54, 101-142. https://doi.org/10.1016/j.najef.2020.101142

Chen, F., Zhang, T., \& Ma, J. (2020). Financial education and consumer financial planning: Evidence from China. South Asian Journal of Social Studies and Economics, 7(2), 49-60. https://doi.org/10.9734/sajsse/2020/v7i230188

Chiteji, N. S., \& Stafford, F. P. (1999). Portfolio choices of parents and their children as young adults: Asset accumulation by African-American families. American Economic Review, 89(2), 377-380.

Christelis, D., Jappelli, T., \& Padula, M. (2010). Cognitive abilities and portfolio choice. European Economic Review, 54(1), 18-38.

Chu, Z., Wang, Z., Xiao, J. J., \& Zhang, W. (2017). Financial literacy, portfolio choice and financial wellbeing. Social Indicators Research, 132(2), 799-820.

Clark, R. L., Lusardi, A., \& Mitchell, O. S. (2014). Financial knowledge and 401 (k) investment performance (NBER working paper No. w20137). National Bureau of Economic Research. https://www.nber.org/papers/w20137

Clark, R., Lusardi, A., \& Mitchell, O. S. (2017). Employee financial literacy and retirement plan behavior: A case study. Economic Inquiry, 55(1), 248-259.

Collins, J. M., \& O'Rourke, C. M. (2010). Financial education and counseling-Still holding promise. Journal of Consumer Affairs, 44(3), 483-498.

Cupák, A., Fessler, P., Hsu, J. W., \& Paradowski, P. R. (2020). Confidence, financial literacy and investment in risky assets: Evidence from the Survey of Consumer Finances (FEDS Working Paper No. 2020-004). Finance and Economics Discussion Series. https://doi.org/10.17016/FEDS.2020.004

Delavande, A., Rohwedder, S., \& Willis, R. J. (2008). Preparation for retirement, financial literacy and cognitive resources. Michigan Retirement Research Center Research Paper, (2008-190).

Dimmock, S. G., \& Kouwenberg, R. (2010). Loss-aversion and household portfolio choice. Journal of Empirical Finance, 17(3), 441-459.

Fan, L., \& Chatterjee, S. (2019). Financial socialization, financial education, and student loan debt. Journal of Family and Economic Issues, 40(1), 74-85.

Fedorova E. A., Nekhaenko V. V., \& Dovzhenko S. E. (2015). Impact of financial literacy of the population of the Russian Federation on behavior on financial market: Empirical evaluation. Studies on Russian Economic Development, 26(4), 394-402.

Feng, X., Lu, B., Song, X., \& Ma, S. (2019). Financial literacy and household finances: A Bayesian twopart latent variable modeling approach. Journal of Empirical Finance, 51(5),119-137.

Fernandes, D., Lynch Jr, J. G., \& Netemeyer, R. G. (2014). Financial literacy, financial education, and downstream financial behaviors. Management Science, 60(8), 1861-1883.

Frijters, P., Johnston, D. W., Shields, M. A., \& Sinha, K. (2015). A lifecycle perspective of stock market performance and wellbeing. Journal of Economic Behavior and Organization, 112, 237-250.

Gan, L., Yin, Z., Jia, N., Xu, S., Ma, S., \& Zheng, L. (2013). Data you need to know about China: Research report of China household Finance Survey 2012. Springer Science \& Business Media.

Gelman, A., \& Stern, H. (2006). The difference between "significant" and "not significant" is not itself statistically significant. American Statistician, 60(4), 328-331. 
Georgarakos, D., \& Pasini, G. (2011). Trust, sociability, and stock market participation. Review of Finance, 15(4), 693-725.

Goyal, K., \& Kumar, S. (2020). Financial literacy: A systematic review and bibliometric analysis. International Journal of Consumer Studies. Early View. https://doi.org/10.1111/ijcs. 12605

Graham, J. R., Harvey, C. R., \& Huang, H. (2009). Investor competence, trading frequency, and home bias. Management Science, 55(7), 1094-1106.

Greene, W.H. (2018). Econometric Analysis (8th ed.), Pearson Prentice Hall.

Grinblatt, M., Keloharju, M., \& Linnainmaa, J. (2011). IQ and stock market participation. Journal of Finance, 66 (6), 2121-2164.

Guiso L., \& Jappelli, T. (2000). Household portfolios in Italy. In L. Guiso, M. Haliassos \& T. Jappel li (Eds.) Household Portfolios. MIT Press.

Guiso, L., Sapienza, P., \& Zingales, L. (2004). The role of social capital in financial development. American Economic Review, 94(3), 526-556.

Guiso, L., \& Sodini, P. (2013). Household finance: An emerging field. In G. Constantinides, M. Harris \& R. Stulz (Eds.). Handbook of the Economics of Finance (2) (pp. 1397-1531). Elsevier.

Hamid, F. S., \& Loke, Y. J. (2020). Financial literacy, money management skill and credit card repayments. International Journal of Consumer Studies. Early View. https://doi.org/10.1111/ijcs.12614

Hastings, J., \& Mitchell, O. S. (2020). How financial literacy and impatience shape retirement wealth and investment behaviors. Journal of Pension Economics \& Finance, 19 (1), 1-20.

Hong, H., Kubik, J. D., \& Stein, J. C. (2004). Social interaction and stock-market participation. The Journal of Finance, 59(1), 137-163.

Huhmann, B.A., \& McQuitty, S. (2009). A model of consumer financial numeracy. International Journal of Bank Marketing, 27(4), 270-293.

Huston S. J. (2012). Financial literacy and the cost of borrowing. International Journal of Consumer Studies, 26(5), 566-572.

Jiang, J., Liao, L., Wang, Z., \& Xiang, H. (2020). Financial literacy and retail investors' financial welfare: Evidence from mutual fund investment outcomes in China. Pacific-Basin Finance Journal, 59, 101242. https://doi.org/10.1016/j.pacfin.2019.101242

Joo, S. (2008). Personal financial wellness. In J. J. Xiao (Ed.), Handbook of Consumer Finance Research (pp. 21-33). Springer.

Joo, S. H., \& Grable, J. E. (2005). Employee education and the likelihood of having a retirement savings program. Journal of Financial Counseling and Planning, 16(1), 37-49.

Kaiser, T., \& Menkhoff, L. (2017). Does financial education impact financial literacy and financial behavior, and if so, when? World Bank Economic Review, 31 (2), 611-630.

Kaiser, T., \& Menkhoff, L. (2019). Financial education in schools: A meta-analysis of experimental studies. Economics of Education Review, 78, 101-930.

Kim, J., Garman, E. T., \& Quach, A. (2005). Workplace financial education participation and retirement savings by employees and their spouses. Journal of Personal Finance, 4(3), 92-108.

Kim, K. T., \& Xiao, J. J. (2020). Racial/ethnic differences in consumer financial capability: The role of financial education. International Journal of Consumer Studies. Early View. https://doi.org/10.1111/ijcs. 12628

Knight, J., \& Yueh, L. (2008). The role of social capital in the labour market in China. Economics of Transition, 16(3), 389-414. 
Li, G. (2014). Information sharing and stock market participation: Evidence from extended families. Review of Economics and Statistics, 96(1), 151-160.

Li, J., Li, Q., \& Wei, X. (2020). Financial literacy, household portfolio choice and investment return. Pacific-Basin Finance Journal, 62, 101-370. https://doi.org/10.1016/j.pacfin.2020.101370

Li, J., Wu, Y., \& Xiao, J. J. (2020). The impact of digital finance on household consumption: Evidence from China. Economic Modelling, 86, 317-326.

Liang, P., \& Guo, S. (2015). Social interaction, internet access and stock market participation-An empirical study in China. Journal of Comparative Economics, 43(4), 883-901.

Liao, L., Xiao, J. J., Zhang, W., \& Zhou, C. (2017). Financial literacy and risky asset holdings: Evidence from China. Accounting and Finance, 57(5), 1383-1415.

Lim, K. L., Soutar, G. N., \& Lee, J. A. (2013). Factors affecting investment intentions: A consumer behaviour perspective. Journal of Financial Services Marketing, 18(4), 301-315.

Lusardi, A., Michaud, P. C., \& Mitchell, O. S. (2017). Optimal financial knowledge and wealth inequality. Journal of Political Economy, 125(2), 431-477.

Lusardi, A., \& Mitchell, O.S. (2014). The economic importance of financial literacy: Theory and evidence. Journal of Economic Literature. 52(1), 5-44.

Lusardi, A. \& Mitchell, O.S. (2007). Financial literacy and retirement preparedness: Evidence and implications for financial education, Business Economics, 42(1), 35-44.

Lusardi, A., \& Mitchell, O. S. (2008). Planning and financial literacy: How do women fare? American Economic Review 98(2), 413-17.

Lusardi, A., \& Mitchell, O. S. (2011a). Financial literacy and planning: Implications for retirement wellbeing. In O. S. Mitchell \& A. Lusardi (Eds.), Financial Literacy: Implications for Retirement Security and the Financial Marketplace (pp. 17-39). Oxford University Press.

Lusardi, A., \& Mitchell, O. S. (2011b). Financial literacy around the world: An overview. Journal of Pension Economics and Finance. 10(4), 497-508.

Lusardi, A., \& Tufano, P. (2009). Teach workers about the peril of debt. Harvard Business Review. November, 22-24.

Lusardi, A., \& Tufano, P. (2015). Debt literacy, financial experiences, and overindebtedness. Journal of Pension Economics and Finance, 14(4), 332-368.

Lusardi, A. (2008). Household saving behavior: The role of financial literacy, information, and financial education programs. (NBER Working Paper No. w13824). National Bureau of Economic Research. https://www.nber.org/papers/w13824

Lusardi, A. (2019). Financial literacy and the need for financial education: Evidence and implications. Swiss Journal of Economics and Statistics. 155, 1-8.

Lyons, A. C. (2008). Risky credit card behavior of college students. In J.J. Xiao (Ed.), Handbook of Consumer Finance Research (pp. 185-207). Springer.

Lyons, A. C. (2004). A profile of financially at-risk college students. Journal of Consumer Affairs, 38(1), 56-80.

Mandell, L., \& Klein, L. S. (2009). The impact of financial literacy education on subsequent financial behavior. Journal of Financial Counseling and Planning, 20(1), 15-24.

Markowitz, H. (1952). Portfolio selection. Journal of Finance, 7(1), 77-91.

Markus, G., \& Alexander, K. (2013). Causal evidence on internet use and stock market participation. University of Munich Working Paper. http://dx.doi.org/10.2139/ssrn.2021158

McCormick, M. H. (2009). The effectiveness of youth financial education: A review of the literature. 
Journal of Financial Counseling and Planning, 20(1), 70-81.

Merton, R. C. (1969). Lifetime portfolio selection under uncertainty: The continuous-time case. Review of Economics and Statistics, 51(3), 247-257.

Michell, O.S, \& Moore, J. F. (1998). Can Americans afford to retire? New evidence on retirement savings adequacy. Journal of Risk Insurance, 65(3), 371-400.

Miller, M., Reichelstein, J., Salas, C., \& Zia, B. (2015). Can you help someone become financially capable? A meta-analysis of the literature. World Bank Research Observer, 30 (2), 220-246.

Mishra, R. (2018). Financial literacy, risk tolerance and stock market participation. Asian Economic and Financial Review, 8(12), 1457-1471.

Modigliani, F., \& Brumberg, R. (1954). Utility analysis and the consumption function: An interpretation of cross-section data. In K. K. Kurihara (Ed.), Post Keynesian economics (pp. 388-436). Rutgers University Press.

Mouna, A. \& Jarboui, A. (2015). Financial literacy and portfolio diversification: An observation from the Tunisian stock market. International Journal of Bank Marketing, 33(6), 808-822.

Murgea, A., \& Reisz, R. D. (2013). Does the market make us happy? The stock market and well-being. Economia Politica, 30(1), 69-86.

Mustillo, S. A., Lizardo, O. A., \& McVeigh, R. M. (2018). Editors' comment: A few guidelines for quantitative submissions. American Sociological Review, 83(6), 1281-1283. https://doi.org/10.1177/0003122418806282.

Organization for Economic Co-operation and Development (OECD). (2005). Improving financial literacy: Analysis of issues and policies. OECD.

Paul, J., \& Mas, E. (2020). Toward a 7-P framework for international marketing. Journal of Strategic Marketing, 28(8), 681-701. https://doi.org/10.1080/0965254X.2019.1569111

Peng, T. C. M., Bartholomae, S., Fox, J. J., \& Cravener, G. (2007). The impact of personal finance education delivered in high school and college courses. Journal of Family and Economic Issues, 28(2), 265-284.

Poterba, J. M., \& Samwick, A. A. (2003). Taxation and household portfolio composition: US evidence from the 1980s and 1990s. Journal of Public Economics, 87(1), 5-38.

Reyers, M. (2019). Financial capability and emergency savings among South Africans living above and below the poverty line. International Journal of Consumer Studies, 43(4), 335-347.

Rooij v. M., Lusardi, A., \& Alessie, R. (2011). Financial literacy and stock market participation. Journal of Financial Economics, 101 (2), 449-472.

Ryack, K. (2011). The impact of family relationships and financial education on financial risk tolerance. Financial Services Review, 20(3),181-193.

Skimmyhorn, W. (2012). Essays in behavioral household finance. PhD thesis, Harvard Kennedy School, Cambridge, MA. http://nrs.harvard.edu/urn-3:HUL.InstRepos:9369052

Sobel, M. E. (1986). Some new results on indirect effects and their standard errors in covariance structure models. Sociological Methodology 16, 159-86.

Tajurahim, N. N. S., Abu Bakar, E., Md Jusoh, Z., Ahmad, S. O., \& Muhammad Arif, A. M. (2020). The effect of intensity of consumer education, self-efficacy, personality traits and social media on consumer empowerment. International Journal of Consumer Studies, 44(6), 511-520. https://doi.org/10.1111/ijcs. 12585

Utkarsh, Pandey, A., Ashta, A., Spiegelman, E., \& Sutan, A. (2020). Catch them young: Impact of financial socialization, financial literacy and attitude towards money on financial well-being of 
young adults. International Journal of Consumer Studies, 44(6), 531-541. https://doi.org/10.1111/ijcs.12583

Urban, C., Schmeiser, M., Collins, J. M., \& Brown, A. (2020). The effects of high school personal financial education policies on financial behavior. Economics of Education Review, 78, 101786. https://doi.org/10.1016/j.econedurev.2018.03.006

Vissing-Jorgensen, A. (2002). Towards an explanation of household portfolio choice heterogeneity: Nonfinancial income and participation cost structures (NBER Working Paper No. w8884). National Bureau of Economic Research. https://www.nber.org/papers/w8884

Wagner, J. (2019). Financial education and financial literacy by income and education groups. Journal of Financial Counseling and Planning, 30(1), 132-141.

Walstad, W. B., Rebeck, K., \& MacDonald, R. A. (2010). The effects of financial education on the financial knowledge of high school students. Journal of Consumer Affairs, 44(2), 336-357.

Willis, L. E. (2011). The financial education fallacy. American Economic Review, 101(3), 429-34.

Xiao, J. J. (2015). Consumer economic wellbeing. Springer.

Xiao, J. J., Ahn, S. Y., Serido, J., \& Shim, S. (2014). Earlier financial literacy and later financial behaviour of college students. International Journal of Consumer Studies, 38(6), 593-601.

Xiao, J. J., \& O’Neill, B. (2016). Consumer financial education and financial capability. International Journal of Consumer Studies, 40(6), 712-721.

Xiao, J. J., \& Porto, N. (2017). Financial education and financial satisfaction: Financial literacy, behavior, and capability as mediators. International Journal of Bank Marketing, 35(5), 805-817.

Xiao, J. J., \& Tao, C. (2020). Consumer finance / household finance: The definition and scope. China Finance Review International. Ahead-of-print. https://doi.org/10.1108/CFRI-04-2020-0032

Xiao, J. J., Porto, N., \& Mason, I. M. (2020). Financial capability of student loan holders who are college graduates, dropouts, and enrollees. Journal of Consumer Affairs. Early View. https://doi.org/10.1111/joca.12336

Xiao, J. J., Serido, J., \& Shim, S. (2012). Financial education, financial knowledge, and risky credit behavior of college students. In D. Lamdin (Ed.), Consumer knowledge and financial decisions (pp. 113-128). Springer.

Yoong, J. (2011). Financial illiteracy and stock market participation: evidence from the RAND American Life Panel. In O. S. Mitchell \& A. Lusardi (Eds.), Financial Literacy: Implications for Retirement Security and the Financial Marketplace (pp.76-97). Oxford University Press. 
Table 1. Variables definition

\begin{tabular}{|c|c|}
\hline Vari & Attribute \\
\hline $\begin{array}{l}\text { Financial } \\
(\text { finedu })\end{array}$ & $\begin{array}{l}\text { Based on the survey question "Have you ever taken an economic or } \\
\text { financial class?" If yes, finedu=1, otherwise, fined } u=0 \text {. }\end{array}$ \\
\hline $\begin{array}{l}\text { Risky financial asset } \\
\text { holding risfinass_h }\end{array}$ & $\begin{array}{l}\text { If the household allocate risky financial assets, risfinass_h } h=1 \text {, } \\
\text { otherwise, risfinass_h } h=0 \text {. }\end{array}$ \\
\hline $\begin{array}{l}\text { Financial } \quad \text { literacy } \\
\text { (finliter })\end{array}$ & $\begin{array}{l}\text { The number of correct answers among three financial literacy } \\
\text { questions. finliter }=0,1,2,3 \text {. }\end{array}$ \\
\hline $\begin{array}{l}\text { Economic and financial } \\
\text { information search } \\
(\text { ecofin_search) }\end{array}$ & $\begin{array}{l}\text { The degree of care for the economic and financial information. 1- Not } \\
\text { at all, 2- Seldomly concerned, 3- Generally concerned, 4- Very } \\
\text { concerned, 5- Extremely concerned. }\end{array}$ \\
\hline Risk tolerance & $\begin{array}{l}\text { The preference for the degree of risk in financial products. 1- } \\
\text { Unwilling to carry any risk, 2- slight risk and return, 3- average risk } \\
\text { and return, 4- slightly high-risk and slightly high-return, 5- high-risk } \\
\text { and high-return. }\end{array}$ \\
\hline Gender (Gender_male) & $\begin{array}{l}\text { Household gender, male: gender_male }=1 \text {, female: } \\
\text { gender_male }=0\end{array}$ \\
\hline Age & the age of respondents, age $\geqslant 18$ \\
\hline $\begin{array}{l}\text { Education } \\
\text { (education) }\end{array}$ & $\begin{array}{l}\text { The education years of the respondent, not in school:0, Primary } \\
\text { school:6, Junior high school:9, Senior high school/Technical high } \\
\text { school:12, Junior college/ Vocational college:15, Bachelor's } \\
\text { degree:16, Master's degree:18, Doctorate degree: } 23 \text {. }\end{array}$ \\
\hline Politics status (politcstat) & $\begin{array}{l}\text { Whether the respondent is member of the Communist Party of China } \\
\text { or not. If yes, politcstat }=1 \text {, otherwise, politcstat }=0\end{array}$ \\
\hline Marriage & $\begin{array}{l}\text { If the respondent is married, marriage }=1 \text {, otherwise, } \\
\text { marriage }=0\end{array}$ \\
\hline Hukou (hukou_agr) & $\begin{array}{l}\text { If the registered residence type is Agricultural residence, } \\
\text { hukou_agr }=1 \text {, otherwise, hukou_agr }=0 \text {. }\end{array}$ \\
\hline Income & $\begin{array}{l}\text { The total amount of household income in last year, including the wage } \\
\text { income with after tax wage, after tax bonus, after-tax subsidies or } \\
\text { subsidy in-kind and money obtained from the second job, agricultural } \\
\text { income, business income and rental income. }\end{array}$ \\
\hline $\begin{array}{l}\text { Work in financial sector } \\
(\text { fin_job) }\end{array}$ & $\begin{array}{l}\text { Whether the household respondent works in financial sector, } \\
\text { yes: fin_job }=1 \text {, no: fin_job }=0\end{array}$ \\
\hline Household size ( $h$ h_size) & The number of family members living in the household \\
\hline Rural & Whether the household is in a rural or urban region, 1-rural, 0 -urban \\
\hline East & $\begin{array}{l}\text { Whether the household is in an eastern region of China or not, 1-east, } \\
0 \text { - non-east }\end{array}$ \\
\hline West & $\begin{array}{l}\text { Whether the household lives is in a western region of China or not, } 1 \text { - } \\
\text { west, } 0 \text { - non-west }\end{array}$ \\
\hline
\end{tabular}


Table 2 Summary description of statistics $(\mathrm{N}=32,554)$

\begin{tabular}{clcccc}
\hline & Variable name & Mean & Std. & Min & Max \\
\hline risfinass_h & Risky financial asset holding & 0.177 & 0.382 & 0 & 1 \\
finedu & Financial education & 0.073 & 0.259 & 0 & 1 \\
finliter & Financial literacy & 0.985 & 0.916 & 0 & 3 \\
ecofin_search & economic and financial information & 2.151 & 1.095 & 1 & 5 \\
& search & & & & \\
Risk_tolerance & Risk tolerance & 1.922 & 1.171 & 1 & 5 \\
Gender_male & Gender & 0.528 & 0.499 & 0 & 1 \\
age & Age & 51.199 & 14.637 & 18 & 103 \\
education & Education years & 9.463 & 4.192 & 0 & 23 \\
politcstat & Politics status & 0.164 & 0.371 & 0 & 1 \\
marriage & Marriage & 0.856 & 0.352 & 0 & 1 \\
hukou_agr & Hukou & 0.514 & 0.499 & 0 & 1 \\
lnincome & Income & 7.328 & 4.953 & 0 & 15.907 \\
fin_job & Work in financial sector & 0.013 & 0.114 & 0 & 1 \\
hh_size & Household size & 3.702 & 1.943 & 1 & 36 \\
rural & Rural & 0.294 & 0.456 & 0 & 1 \\
east & East & 0.502 & 0.500 & 0 & 1 \\
west & West & 0.234 & 0.423 & 0 & 1 \\
\hline
\end{tabular}


Table 3 Details of financial asset holdings $(\mathrm{N}=32,554)$

\begin{tabular}{clll}
\hline & Types of Financial Assets & Frequency & Percent (\%) \\
\hline & Stocks & 3,110 & 9.553 \\
& Funds & 1,211 & 3.720 \\
& Wealth Management Products & 3,163 & 9.716 \\
Risky financial & Bonds & 191 & 0.587 \\
& Derivatives & 21 & 0.065 \\
& Non-RMB Assets & 60 & 0.184 \\
& Precious Metal & 175 & 0.538 \\
& Total & 5,769 & 17.721 \\
\hline \multirow{2}{*}{ assets } & Demand Deposit & 19,436 & 59.704 \\
& Deposit & 6,461 & 19.847 \\
& Other Financial assets & 20 & 0.061 \\
& Cash & 30,486 & 93.647 \\
& Lent-out Money & 2,843 & 8.733 \\
\hline Total financial assets & & 31,142 & 95.663 \\
\hline
\end{tabular}


Table 4 Row percentages of cross tabulation between education years and financial education ( $N=32,554)$

\begin{tabular}{ccc|c}
\hline Education years & \multicolumn{2}{|c}{ Financial education } & Total \\
& 0 & 1 & \\
\hline 0 & 99.16 & 0.84 & 100.00 \\
6 & 99.10 & 0.90 & 100.00 \\
9 & 97.52 & 2.48 & 100.00 \\
12 & 92.24 & 7.76 & 100.00 \\
15 & 77.54 & 22.46 & 100.00 \\
16 & 71.48 & 28.52 & 100.00 \\
18 & 57.79 & 42.21 & 100.00 \\
23 & 77.55 & 22.45 & 100.00 \\
\hline Total & 92.74 & 7.26 & 100.00 \\
\hline
\end{tabular}


Table 5 Results of basic Probit regression

(1)

risfinass_h
(2)

risfinass_h
(3)

risfinass_h
(4)

Average marginal

effects

$$
\begin{array}{r}
1.087^{* * *} \\
(0.027)
\end{array}
$$

$0.462^{* * *}$

(0.032)

$-0.033 *$

(0.019)

$-0.007 * * *$

$(0.001)$

$0.111^{* * *}$

(0.004)

$0.096^{* * *}$

$(0.025)$

marriage

hukou_agr

$0.084 * * *$

(0.028)

$-0.443^{* * *}$

$(0.024)$

$0.017 * * *$

$(0.002)$

0.111 *

(0.067)

$-0.023^{* * *}$

(0.006)

$-0.559 * * *$

(0.036)

$0.390^{* * *}$

(0.025)

0.029

(0.031)

$$
-1.035^{* * *}
$$

$-1.948 * * *$

(0.079)

32,554

0.261

NO

$0.453 * * *$

$(0.032)$

$-0.033^{*}$

$(0.020)$

$-0.008 * * *$

(0.001)

$0.110^{* * *}$

(0.004)

$0.114 * * *$

(0.025)

$0.093 * * *$

(0.028)

$-0.468 * * *$

(0.025)

$0.015^{* * *}$

(0.002)

$0.150^{* *}$

$(0.069)$

$-0.024 * * *$

(0.007)

$-0.526^{* * *}$

(0.037)

$0.283 * * *$

$(0.065)$

-0.181 *

(0.105)

$-1.658^{* * *}$

Observation

32,554

0.052

$(0.092)$

R-squared

NO

32,554

0.283

32,554

Province FE

Note: Robust standard errors in parentheses. R-squared is pseudo R-squared in Probit regression. *** $\mathrm{p}<0.01, * * \mathrm{p}<0.05, * \mathrm{p}<0.1$ 
Table 6 Financial literacy as mediator

(1) (2) (3) (4)

risfinass_h Average marginal finliter risfinass_h Average marginal

\begin{tabular}{|c|c|c|c|c|c|}
\hline & & effects & & & effects \\
\hline \multirow[t]{2}{*}{ finedu } & $0.453 * * *$ & $0.085 * * *$ & $0.235 * * *$ & $0.413 * * *$ & $0.075 * * *$ \\
\hline & $(0.032)$ & $(0.006)$ & $(0.020)$ & $(0.033)$ & $(0.006)$ \\
\hline \multirow[t]{2}{*}{ finliter } & & & & $0.246^{* * *}$ & $0.045 * * *$ \\
\hline & & & & $(0.011)$ & $(0.002)$ \\
\hline \multirow[t]{2}{*}{ Gender_male } & $-0.033^{*}$ & $-0.006^{*}$ & $0.077 * * *$ & $-0.057 * * *$ & $-0.010 * * *$ \\
\hline & $(0.020)$ & $(0.004)$ & $(0.009)$ & $(0.020)$ & $(0.004)$ \\
\hline \multirow[t]{2}{*}{ age } & $-0.008 * * *$ & $-0.002 * * *$ & $-0.011 * * *$ & $-0.006 * * *$ & $-0.001 * * *$ \\
\hline & $(0.001)$ & $(0.0002)$ & $(0.0004)$ & $(0.001)$ & $(0.0002)$ \\
\hline \multirow[t]{2}{*}{ education } & $0.110^{* * *}$ & $0.021 * * *$ & $0.055^{* * *}$ & $0.096^{* * *}$ & $0.018 * * *$ \\
\hline & $(0.004)$ & $(0.001)$ & $(0.001)$ & $(0.004)$ & $(0.001)$ \\
\hline \multirow[t]{2}{*}{ politcstat } & $0.114 * * *$ & $0.021 * * *$ & $0.095 * * *$ & $0.101 * * *$ & $0.018 * * *$ \\
\hline & $(0.025)$ & $(0.005)$ & $(0.013)$ & $(0.026)$ & $(0.005)$ \\
\hline \multirow[t]{2}{*}{ marriage } & $0.093 * * *$ & $0.017 * * *$ & $0.036^{* *}$ & $0.082 * * *$ & $0.015 * * *$ \\
\hline & $(0.028)$ & $(0.005)$ & $(0.013)$ & $(0.029)$ & $(0.005)$ \\
\hline \multirow[t]{2}{*}{ hukou_agr } & $-0.468 * * *$ & $-0.087 * * *$ & $-0.191 * * *$ & $-0.438 * * *$ & $-0.080 * * *$ \\
\hline & $(0.025)$ & $(0.005)$ & $(0.012)$ & $(0.026)$ & $(0.005)$ \\
\hline \multirow[t]{2}{*}{ lnincome } & $0.015 * * *$ & $0.003 * * *$ & $0.004 * * *$ & $0.015 * * *$ & $0.027 * * *$ \\
\hline & $(0.002)$ & $(0.0004)$ & $(0.001)$ & $(0.002)$ & $(0.0004)$ \\
\hline \multirow[t]{2}{*}{ fin_job } & $0.150 * *$ & $0.028 * *$ & $0.230 * * *$ & 0.104 & 0.019 \\
\hline & $(0.069)$ & $(0.013)$ & $(0.042)$ & $(0.069)$ & $(0.013)$ \\
\hline \multirow[t]{2}{*}{ hh_size } & $-0.024 * * *$ & $-0.005^{* * *}$ & $-0.008^{* *}$ & $-0.022 * * *$ & $-0.004 * * *$ \\
\hline & $(0.007)$ & $(0.001)$ & $(0.002)$ & $(0.007)$ & $(0.001)$ \\
\hline \multirow[t]{2}{*}{ rural } & $-0.526 * * *$ & $-0.098 * * *$ & $-0.137 * * *$ & $-0.492 * * *$ & $-0.089 * * *$ \\
\hline & $(0.037)$ & $(0.007)$ & $(0.012)$ & $(0.038)$ & $(0.007)$ \\
\hline \multirow[t]{2}{*}{ east } & $0.283 * * *$ & $0.053 * * *$ & $0.189 * * *$ & $0.243 * * *$ & $0.044 * * *$ \\
\hline & $(0.065)$ & $(0.012)$ & $(0.032)$ & $(0.065)$ & $(0.012)$ \\
\hline \multirow[t]{2}{*}{ west } & $-0.181 *$ & $-0.034 *$ & $0.105 * *$ & $-0.219 * *$ & $-0.040 * *$ \\
\hline & $(0.105)$ & $(0.020)$ & $(0.042)$ & $(0.106)$ & $(0.019)$ \\
\hline \multirow[t]{2}{*}{ constant } & $-1.658 * * *$ & & $1.057 * * *$ & $-1.905 * * *$ & \\
\hline & $(0.092)$ & & $(0.040)$ & $(0.093)$ & \\
\hline Observation & 32,554 & 32,554 & 32,554 & 32,554 & 32,554 \\
\hline R-squared & 0.283 & & 0.255 & 0.298 & \\
\hline Province FE & YES & YES & YES & YES & YES \\
\hline
\end{tabular}

Note: Robust standard errors in parentheses. R-squared is pseudo R-squared in Probit regression. *** $\mathrm{p}<0.01, * * \mathrm{p}<0.05, * \mathrm{p}<0.1$ 
Table 7 Economic and financial information search as mediator

\begin{tabular}{|c|c|c|c|c|c|}
\hline & $\begin{array}{c}(1) \\
\text { risfinass_h }\end{array}$ & $\begin{array}{c}\text { (2) } \\
\text { Average marginal } \\
\text { effects }\end{array}$ & ecofin_search & $\begin{array}{c}(4) \\
\text { risfinass_h }\end{array}$ & $\begin{array}{l}\text { Average marginal } \\
\text { effects }\end{array}$ \\
\hline finedu & $\begin{array}{c}0.453 * * * \\
(0.032)\end{array}$ & $\begin{array}{c}0.085 * * * \\
(0.006)\end{array}$ & $\begin{array}{c}0.787 * * * \\
(0.024)\end{array}$ & $\begin{array}{c}0.240 * * * \\
(0.034)\end{array}$ & $\begin{array}{c}0.043 * * * \\
(0.006)\end{array}$ \\
\hline ecofin_search & & & & $\begin{array}{c}0.310 * * * \\
(0.010)\end{array}$ & $\begin{array}{c}0.055^{* * *} \\
(0.002)\end{array}$ \\
\hline Gender_male & $\begin{array}{l}-0.033 * \\
(0.020)\end{array}$ & $\begin{array}{l}-0.006^{*} \\
(0.004)\end{array}$ & $\begin{array}{c}0.238 * * * \\
(0.011)\end{array}$ & $\begin{array}{c}-0.117 * * * \\
(0.021)\end{array}$ & $\begin{array}{c}-0.021 * * * \\
(0.004)\end{array}$ \\
\hline age & $\begin{array}{c}-0.008^{* * * *} \\
(0.001)\end{array}$ & $\begin{array}{c}-0.002 * * * \\
(0.0002)\end{array}$ & $\begin{array}{c}-0.004 * * * \\
(0.001)\end{array}$ & $\begin{array}{c}-0.008 * * * \\
(0.001)\end{array}$ & $\begin{array}{c}-0.001 * * * \\
(0.0002)\end{array}$ \\
\hline education & $\begin{array}{c}0.110 * * * \\
(0.004)\end{array}$ & $\begin{array}{c}0.021 * * * \\
(0.001)\end{array}$ & $\begin{array}{c}0.053 * * * \\
(0.002)\end{array}$ & $\begin{array}{c}0.094 * * * \\
(0.004)\end{array}$ & $\begin{array}{c}0.017 * * * \\
(0.001)\end{array}$ \\
\hline politcstat & $\begin{array}{c}0.114 * * * \\
(0.025)\end{array}$ & $\begin{array}{c}0.021 * * * \\
(0.005)\end{array}$ & $\begin{array}{c}0.158 * * * \\
(0.017)\end{array}$ & $\begin{array}{c}0.095 * * * \\
(0.026)\end{array}$ & $\begin{array}{c}0.017 * * * \\
(0.005)\end{array}$ \\
\hline marriage & $\begin{array}{c}0.093 * * * \\
(0.028)\end{array}$ & $\begin{array}{c}0.017 * * * \\
(0.005)\end{array}$ & $\begin{array}{c}0.084 * * * \\
(0.016)\end{array}$ & $\begin{array}{l}0.061 * * \\
(0.029)\end{array}$ & $\begin{array}{l}0.011 * * \\
(0.005)\end{array}$ \\
\hline hukou_agr & $\begin{array}{c}-0.468^{* * *} \\
(0.025)\end{array}$ & $\begin{array}{c}-0.087^{* * *} \\
(0.005)\end{array}$ & $\begin{array}{c}-0.150 * * * \\
(0.015)\end{array}$ & $\begin{array}{c}-0.442 * * * \\
(0.026)\end{array}$ & $\begin{array}{c}-0.079 * * * \\
(0.005)\end{array}$ \\
\hline lnincome & $\begin{array}{c}0.015 * * * \\
(0.002)\end{array}$ & $\begin{array}{l}0.003 * * * \\
(0.0004)\end{array}$ & $\begin{array}{c}0.001 \\
(0.001)\end{array}$ & $\begin{array}{c}0.015 * * * \\
(0.002)\end{array}$ & $\begin{array}{c}0.003 * * * \\
(0.0004)\end{array}$ \\
\hline fin_job & $\begin{array}{l}0.150 * * \\
(0.069)\end{array}$ & $\begin{array}{l}0.028 * * \\
(0.013)\end{array}$ & $\begin{array}{c}0.605 * * * \\
(0.049)\end{array}$ & $\begin{array}{l}-0.028 \\
(0.071)\end{array}$ & $\begin{array}{l}-0.005 \\
(0.013)\end{array}$ \\
\hline$h h \_s i z e$ & $\begin{array}{c}-0.024 * * * \\
(0.007)\end{array}$ & $\begin{array}{c}-0.005^{* * *} \\
(0.001)\end{array}$ & $\begin{array}{c}-0.008 * * \\
(0.003)\end{array}$ & $\begin{array}{c}-0.019 * * * \\
(0.007)\end{array}$ & $\begin{array}{c}-0.003 * * * \\
(0.001)\end{array}$ \\
\hline rural & $\begin{array}{c}-0.526^{* * *} \\
(0.037)\end{array}$ & $\begin{array}{c}-0.098^{* * *} \\
(0.007)\end{array}$ & $\begin{array}{c}0.013 \\
(0.015)\end{array}$ & $\begin{array}{c}-0.556^{* * *} \\
(0.040)\end{array}$ & $\begin{array}{c}-0.099 * * * \\
(0.007)\end{array}$ \\
\hline east & $\begin{array}{c}0.283 * * * \\
(0.065)\end{array}$ & $\begin{array}{c}0.053 * * * \\
(0.012)\end{array}$ & $\begin{array}{c}0.122 * * * \\
(0.039)\end{array}$ & $\begin{array}{c}0.275^{* * *} \\
(0.066)\end{array}$ & $\begin{array}{c}0.049 * * * \\
(0.012)\end{array}$ \\
\hline west & $\begin{array}{l}-0.181 * \\
(0.105)\end{array}$ & $\begin{array}{l}-0.034 * \\
(0.020)\end{array}$ & $\begin{array}{c}0.188 * * * \\
(0.051)\end{array}$ & $\begin{array}{c}-0.218^{* *} \\
(0.108)\end{array}$ & $\begin{array}{c}-0.039 * * \\
(0.019)\end{array}$ \\
\hline constant & $\begin{array}{c}-1.658^{* * *} \\
(0.092)\end{array}$ & & $\begin{array}{c}1.579 * * * \\
(0.049)\end{array}$ & $\begin{array}{c}-2.145^{* * *} \\
(0.096)\end{array}$ & \\
\hline Observation & 32,554 & 32,554 & 32,554 & 32,554 & 32,554 \\
\hline R-squared & 0.283 & & 0.184 & 0.317 & \\
\hline Province FE & YES & YES & YES & YES & YES \\
\hline
\end{tabular}

Note: Robust standard errors in parentheses. R-squared is pseudo R-squared in Probit regression. *** $\mathrm{p}<0.01, * * \mathrm{p}<0.05,{ }^{*} \mathrm{p}<0.1$ 
Table 8 Risk tolerance as mediator

\begin{tabular}{|c|c|c|c|c|c|}
\hline & $\begin{array}{c}(1) \\
\text { risfinass_h }\end{array}$ & $\begin{array}{c}\text { (2) } \\
\text { Average marginal } \\
\text { effects }\end{array}$ & $\begin{array}{c}\text { (3) } \\
\text { Risk_tolerance }\end{array}$ & $\begin{array}{c}\text { (4) } \\
\text { risfinass_h }\end{array}$ & $\begin{array}{c}(5) \\
\text { Average } \\
\text { marginal effects }\end{array}$ \\
\hline finedu & $\begin{array}{c}0.453 * * * \\
(0.032)\end{array}$ & $\begin{array}{c}0.085 * * * \\
(0.006)\end{array}$ & $\begin{array}{c}0.475 * * * \\
(0.026)\end{array}$ & $\begin{array}{c}0.364 * * * \\
(0.033)\end{array}$ & $\begin{array}{c}0.065^{* * *} \\
(0.006)\end{array}$ \\
\hline Risk_tolerance & & & & $\begin{array}{c}0.248 * * * \\
(0.008)\end{array}$ & $\begin{array}{c}0.045 * * * \\
(0.001)\end{array}$ \\
\hline Gender_male & $\begin{array}{l}-0.033 * \\
(0.020)\end{array}$ & $\begin{array}{l}-0.006^{*} \\
(0.004)\end{array}$ & $\begin{array}{c}0.236^{* * *} \\
(0.012)\end{array}$ & $\begin{array}{c}-0.107 * * * \\
(0.020)\end{array}$ & $\begin{array}{c}-0.019 * * * \\
(0.004)\end{array}$ \\
\hline age & $\begin{array}{c}-0.008^{* * *} \\
(0.001)\end{array}$ & $\begin{array}{c}-0.002 * * * \\
(0.0002)\end{array}$ & $\begin{array}{c}-0.023^{* * *} \\
(0.001)\end{array}$ & $\begin{array}{c}-0.002 * * * \\
(0.001)\end{array}$ & $\begin{array}{c}-0.0004 * * * \\
(0.0002)\end{array}$ \\
\hline education & $\begin{array}{c}0.110 * * * \\
(0.004)\end{array}$ & $\begin{array}{c}0.021 * * * \\
(0.001)\end{array}$ & $\begin{array}{c}0.029 * * * \\
(0.002)\end{array}$ & $\begin{array}{c}0.102 * * * \\
(0.004)\end{array}$ & $\begin{array}{c}0.018 * * * \\
(0.001)\end{array}$ \\
\hline politcstat & $\begin{array}{c}0.114 * * * \\
(0.025)\end{array}$ & $\begin{array}{c}0.021 * * * \\
(0.005)\end{array}$ & $\begin{array}{c}0.050 * * * \\
(0.017)\end{array}$ & $\begin{array}{c}0.117 * * * \\
(0.026)\end{array}$ & $\begin{array}{c}0.021 * * * \\
(0.005)\end{array}$ \\
\hline marriage & $\begin{array}{c}0.093 * * * \\
(0.028)\end{array}$ & $\begin{array}{c}0.017 * * * \\
(0.005)\end{array}$ & $\begin{array}{c}-0.117 * * * \\
(0.017)\end{array}$ & $\begin{array}{c}0.116^{* * * *} \\
(0.029)\end{array}$ & $\begin{array}{c}0.021 * * * \\
(0.005)\end{array}$ \\
\hline hukou_agr & $\begin{array}{c}-0.468 * * * \\
(0.025)\end{array}$ & $\begin{array}{c}-0.087^{* * *} \\
(0.005)\end{array}$ & $\begin{array}{c}-0.122 * * * \\
(0.016)\end{array}$ & $\begin{array}{c}-0.449 * * * \\
(0.026)\end{array}$ & $\begin{array}{c}-0.081 * * * \\
(0.005)\end{array}$ \\
\hline lnincome & $\begin{array}{c}0.015^{* * *} \\
(0.002)\end{array}$ & $\begin{array}{l}0.003 * * * \\
(0.0004)\end{array}$ & $\begin{array}{c}0.004 * * * \\
(0.001)\end{array}$ & $\begin{array}{c}0.014^{* * *} \\
(0.002)\end{array}$ & $\begin{array}{l}0.003 * * * \\
(0.0004)\end{array}$ \\
\hline fin_job & $\begin{array}{l}0.150 * * \\
(0.069)\end{array}$ & $\begin{array}{l}0.028 * * \\
(0.013)\end{array}$ & $\begin{array}{c}0.281 * * * \\
(0.054)\end{array}$ & $\begin{array}{c}0.098 \\
(0.070)\end{array}$ & $\begin{array}{c}0.018 \\
(0.013)\end{array}$ \\
\hline hh_size & $\begin{array}{c}-0.024 * * * \\
(0.007)\end{array}$ & $\begin{array}{c}-0.005^{* * *} \\
(0.001)\end{array}$ & $\begin{array}{l}0.0007 \\
(0.003)\end{array}$ & $\begin{array}{c}-0.023 * * * \\
(0.007)\end{array}$ & $\begin{array}{c}-0.004 * * * \\
(0.001)\end{array}$ \\
\hline rural & $\begin{array}{c}-0.526^{* * *} \\
(0.037)\end{array}$ & $\begin{array}{c}-0.098 * * * \\
(0.007)\end{array}$ & $\begin{array}{l}-0.008 \\
(0.016)\end{array}$ & $\begin{array}{c}-0.537 * * * \\
(0.039)\end{array}$ & $\begin{array}{c}-0.097 * * * \\
(0.007)\end{array}$ \\
\hline east & $\begin{array}{c}0.283 * * * \\
(0.065)\end{array}$ & $\begin{array}{c}0.053 * * * \\
(0.012)\end{array}$ & $\begin{array}{c}-0.088^{* *} \\
(0.044)\end{array}$ & $\begin{array}{c}0.325 * * * \\
(0.066)\end{array}$ & $\begin{array}{c}0.058 * * * \\
(0.012)\end{array}$ \\
\hline west & $\begin{array}{l}-0.181 * \\
(0.105)\end{array}$ & $\begin{array}{l}-0.034 * \\
(0.020)\end{array}$ & $\begin{array}{c}0.003 \\
(0.056)\end{array}$ & $\begin{array}{l}-0.179 * \\
(0.107)\end{array}$ & $\begin{array}{l}-0.032 * \\
(0.019)\end{array}$ \\
\hline constant & $\begin{array}{c}-1.658^{* * *} \\
(0.092)\end{array}$ & & $\begin{array}{c}2.799 * * * \\
(0.055)\end{array}$ & $\begin{array}{c}-2.385^{* * *} \\
(0.098)\end{array}$ & \\
\hline Observation & 32,554 & 32,554 & 32,554 & 32,554 & 32,554 \\
\hline R-squared & 0.283 & & 0.189 & 0.310 & \\
\hline Province FE & YES & YES & YES & YES & YES \\
\hline
\end{tabular}

Note: Robust standard errors in parentheses. R-squared is pseudo R-squared in Probit regression. *** $\mathrm{p}<0.01, * * \mathrm{p}<0.05, * \mathrm{p}<0.1$ 
Table 9 Sobel test for mediating effects

(1) (2)

risfinass_h

finedu

$0.189 * * *$

(0.008)

finliter

ecofin_search

$0.235 * * *$

(0.018)

$0.176^{* * *}$

(0.008)

Risk_tolerance

Gender_male

age

ducation

politcstat

marriage

hukou_agr

hh_size

ural

east

west

constant

Observation

R-squared

Province FE

Sobel

Proportion of total effect that is

(3)

$(0.001)$

(0.002)

(0.001)

$0.039 * * * \quad 0.090 * * * \quad 0.034 * * *$

$\begin{array}{lll}(0.005) & (0.013) \quad(0.005)\end{array}$

$-0.0003 \quad 0.039 * * * \quad-0.003$

$(0.005)$

(0.013) (0.005)

$$
\text { (0.005) }
$$

(0.012)

(0.005)

$0.004 * * *$

$0.005 * * *$

$0.004 * * *$

(0.0004)

(0.001)

(0.0004)

$0.086^{* * *}$

$0.215^{* * *}$

(0.017)

(0.017)

(0.001)

(0.002) (0.001)

$$
\text { (0.005) }
$$

$$
\text { (0.012) }
$$

(0.005)

$0.079 * * *$

$0.023 * *$

$0.078 * * *$

(0.005)

(0.011)

(0.005)

$0.013 * *$

$-0.024 *$

$0.015^{* * *}$

(0.005)

$$
\text { (0.013) }
$$

(0.005)

(0.014)

(0.034)

(0.014)

32,544

32,544

32,544

$0.014 * * *$

NO

$7.152 \%$
(4)

(5)

(6)

(7)

isfinass_h ecofin_search risfinass_h Risk_tolerance risfinass_

$0.139 * * *$

$(0.008)$

$0.161 * * *$

(0.008)

$\begin{array}{ccccccc}-0.014 * * * & 0.066^{* * *} & -0.018 * * * & 0.236 * * * & -0.029 * * * & 0.249 * * * & -0.029 * * * \\ (0.004) & (0.009) & (0.004) & (0.011) & (0.004) & (0.012) & (0.004) \\ -0.001 * * * & -0.010 * * * & -0.001 * * * & -0.004 * * * & -0.001 * * * & -0.024 * * * & -0.0001 \\ (0.0002) & (0.0004) & (0.0002) & (0.001) & (0.0002) & (0.001) & (0.0002)\end{array}$

$0.019 * * * \quad 0.057 * * * \quad 0.016 * * * \quad 0.055 * * *$

(0.002)

$0.016^{* * *}$

$0.028 * * *$

$0.018 * * *$

(0.001)

(0.002)

(0.001)

$0.156^{* * *}$

$0.029 * * *$

$0.055^{* * *}$

$0.036 * * *$

(0.016)

(0.005)

(0.017)

(0.005)

$0.086^{* * *}$

$-0.006$

$-0.126^{* * *}$

0.007

(0.016)

(0.005)

(0.017)

(0.005)

$-0.152 * * *$

$-0.099 * * *$

$-0.129 * * *$

$-0.101 * * *$

(0.015)

(0.005)

(0.016)

(0.005)

0.002

$0.004 * * *$

$0.004 * * *$

$0.004 * * *$

(0.001)

(0.0004)

(0.001)

(0.0004)

$0.597 * * *$

$0.048 * * *$

$0.288 * * *$

$0.069 * * *$

(0.050)

(0.017)

$-0.009 * * *$

$-0.005 * *$

(0.054)

(0.017)

(0.003)

(0.001)

$0.008 * * *$

$-0.006 * * *$

0.020

$-0.038 * * *$

(0.003)

(0.001)

(0.015)

(0.005)

$-0.003$

$-0.037 * * *$

0.004

0.079 ***

(0.016)

(0.005)

(0.014)

(0.004)

$0.073^{* * *}$

$0.075 * * *$

$0.082 * * *$

0.008

(0.014)

(0.005)

(0.016)

(0.005)

$1.622 * * *$

-0.036 **

(0.042)

(0.014)

$0.139 * * *$

0.005

32,544

32,544

0.179

0.246

NO

NO
$0.050 * * *$

$26.633 \%$
(0.017)

(0.005)

$2.732 * * *$

$-0.091 * * *$

(0.045)

(0.015)

32,544

32,544

0.180

0.245

NO

$0.028 * * *$

$15.021 \%$ 
Table 10 Heterogeneous associations of financial education on risky financial market participation

\begin{tabular}{|c|c|c|c|c|c|c|}
\hline & $\begin{array}{c}(1) \\
\text { risfinass_h }\end{array}$ & $\begin{array}{c}\text { (2) } \\
\text { Average } \\
\text { marginal effects }\end{array}$ & $\begin{array}{c}(3) \\
\text { risfinass_h }\end{array}$ & $\begin{array}{c}\text { (4) } \\
\text { Average } \\
\text { marginal effects }\end{array}$ & $\begin{array}{c}(5) \\
\text { risfinass_h }\end{array}$ & $\begin{array}{c}(6) \\
\text { Average } \\
\text { marginal effects }\end{array}$ \\
\hline finedu & $\begin{array}{c}0.933 * * * \\
(0.153)\end{array}$ & $\begin{array}{c}0.174 * * * \\
(0.028)\end{array}$ & $\begin{array}{c}0.496 * * * \\
(0.039)\end{array}$ & $\begin{array}{c}0.093 * * * \\
(0.007)\end{array}$ & $\begin{array}{c}0.306 * * * \\
(0.095)\end{array}$ & $\begin{array}{c}0.057 * * * \\
(0.018)\end{array}$ \\
\hline $\begin{array}{l}\text { finedu } \\
\times \text { education }\end{array}$ & $\begin{array}{c}-0.035^{* * *} \\
(0.011)\end{array}$ & $\begin{array}{c}-0.007 * * * \\
(0.002)\end{array}$ & & & & \\
\hline $\begin{array}{l}\text { finedu } \\
\times \text { politcstat }\end{array}$ & & & $\begin{array}{l}-0.125^{*} \\
(0.064)\end{array}$ & $\begin{array}{c}-0.023 * \\
(0.012)\end{array}$ & & \\
\hline fined $u \times$ age & & & & & $\begin{array}{l}0.003 * \\
(0.002)\end{array}$ & $\begin{array}{c}0.001 * \\
(0.0004)\end{array}$ \\
\hline Gender_male & $\begin{array}{l}-0.033 * \\
(0.020)\end{array}$ & $\begin{array}{l}-0.006^{*} \\
(0.004)\end{array}$ & $\begin{array}{c}-0.033 * \\
(0.020)\end{array}$ & $\begin{array}{l}-0.006^{*} \\
(0.004)\end{array}$ & $\begin{array}{l}-0.033^{*} \\
(0.019)\end{array}$ & $\begin{array}{l}-0.006^{*} \\
(0.004)\end{array}$ \\
\hline age & $\begin{array}{c}-0.008 * * * \\
(0.001)\end{array}$ & $\begin{array}{c}-0.002 * * * \\
(0.0002)\end{array}$ & $\begin{array}{c}-0.008 * * * \\
(0.001)\end{array}$ & $\begin{array}{c}-0.002 * * * \\
(0.0002)\end{array}$ & $\begin{array}{c}-0.009 * * * \\
(0.001)\end{array}$ & $\begin{array}{c}-0.002 * * * \\
(0.0002)\end{array}$ \\
\hline education & $\begin{array}{c}0.113 * * * \\
(0.004)\end{array}$ & $\begin{array}{c}0.021 * * * \\
(0.001)\end{array}$ & $\begin{array}{c}0.110 * * * \\
(0.004)\end{array}$ & $\begin{array}{c}0.021 * * * \\
(0.001)\end{array}$ & $\begin{array}{c}0.110 * * * \\
(0.004)\end{array}$ & $\begin{array}{c}0.021 * * * \\
(0.001)\end{array}$ \\
\hline politcstat & $\begin{array}{c}0.114 * * * \\
(0.025)\end{array}$ & $\begin{array}{c}0.021 * * * \\
(0.005)\end{array}$ & $\begin{array}{c}0.135 * * * \\
(0.027)\end{array}$ & $\begin{array}{c}0.025 * * * \\
(0.005)\end{array}$ & $\begin{array}{c}0.113 * * * \\
(0.026)\end{array}$ & $\begin{array}{c}0.021 * * * \\
(0.005)\end{array}$ \\
\hline marriage & $\begin{array}{c}0.915^{* * * *} \\
(0.028)\end{array}$ & $\begin{array}{c}0.017 * * * \\
(0.005)\end{array}$ & $\begin{array}{c}0.095 * * * \\
(0.028)\end{array}$ & $\begin{array}{c}0.018 * * * \\
(0.006)\end{array}$ & $\begin{array}{c}0.089 * * * \\
(0.028)\end{array}$ & $\begin{array}{c}0.017 * * * \\
(0.005)\end{array}$ \\
\hline hukou_agr & $\begin{array}{c}-0.466 * * * \\
(0.025)\end{array}$ & $\begin{array}{c}-0.087 * * * \\
(0.005)\end{array}$ & $\begin{array}{c}-0.467 * * * \\
(0.025)\end{array}$ & $\begin{array}{c}-0.087 * * * \\
(0.005)\end{array}$ & $\begin{array}{c}-0.468 * * * \\
(0.025)\end{array}$ & $\begin{array}{c}-0.087 * * * \\
(0.005)\end{array}$ \\
\hline lnincome & $\begin{array}{c}0.015^{* * * *} \\
(0.002)\end{array}$ & $\begin{array}{c}0.003 * * * \\
(0.0004)\end{array}$ & $\begin{array}{c}0.015 * * * \\
(0.002)\end{array}$ & $\begin{array}{c}0.003 * * * \\
(0.0004)\end{array}$ & $\begin{array}{c}0.015 * * * \\
(0.002)\end{array}$ & $\begin{array}{c}0.003 * * * \\
(0.0004)\end{array}$ \\
\hline fin_job & $\begin{array}{c}0.167 * * \\
(0.068)\end{array}$ & $\begin{array}{c}0.031 * * \\
(0.013)\end{array}$ & $\begin{array}{c}0.146 * * \\
(0.068)\end{array}$ & $\begin{array}{c}0.027 * * \\
(0.013)\end{array}$ & $\begin{array}{c}0.164 * * \\
(0.069)\end{array}$ & $\begin{array}{c}0.031 * * * \\
(0.013)\end{array}$ \\
\hline hh_size & $\begin{array}{c}-0.024 * * * \\
(0.007)\end{array}$ & $\begin{array}{c}-0.004 * * * \\
(0.001)\end{array}$ & $\begin{array}{c}-0.024 * * * \\
(0.007)\end{array}$ & $\begin{array}{c}-0.005^{* * *} \\
(0.001)\end{array}$ & $\begin{array}{c}-0.024 * * * \\
(0.007)\end{array}$ & $\begin{array}{c}-0.005 * * * \\
(0.001)\end{array}$ \\
\hline rural & $\begin{array}{c}-0.526 * * * \\
(0.037)\end{array}$ & $\begin{array}{c}-0.098 * * * \\
(0.007)\end{array}$ & $\begin{array}{c}-0.527 * * * \\
(0.037)\end{array}$ & $\begin{array}{c}-0.098 * * * \\
(0.007)\end{array}$ & $\begin{array}{c}-0.525 * * * \\
(0.037)\end{array}$ & $\begin{array}{c}-0.098 * * * \\
(0.007)\end{array}$ \\
\hline east & $\begin{array}{c}0.288 * * * \\
(0.065)\end{array}$ & $\begin{array}{c}0.054 * * * \\
(0.012)\end{array}$ & $\begin{array}{c}0.282 * * * \\
(0.065)\end{array}$ & $\begin{array}{c}0.053 * * * \\
(0.012)\end{array}$ & $\begin{array}{c}0.283 * * * \\
(0.065)\end{array}$ & $\begin{array}{c}0.053 * * * \\
(0.012)\end{array}$ \\
\hline west & $\begin{array}{c}-0.177^{*} \\
(0.105)\end{array}$ & $\begin{array}{c}-0.033^{*} \\
(0.019)\end{array}$ & $\begin{array}{c}-0.180 * \\
(0.105)\end{array}$ & $\begin{array}{c}-0.034^{*} \\
(0.019)\end{array}$ & $\begin{array}{c}-0.180 * \\
(0.105)\end{array}$ & $\begin{array}{c}-0.034^{*} \\
(0.019)\end{array}$ \\
\hline constant & $\begin{array}{c}-1.695 * * * \\
(0.093)\end{array}$ & & $\begin{array}{c}-1.661 * * * \\
(0.092)\end{array}$ & & $\begin{array}{c}-1.635 * * * \\
(0.093)\end{array}$ & \\
\hline Observation & 32,544 & 32,544 & 32,544 & 32,544 & 32,544 & 32,544 \\
\hline R-squared & 0.283 & & 0.283 & & 0.283 & \\
\hline Province FE & YES & YES & YES & YES & YES & YES \\
\hline
\end{tabular}

Note: Robust standard errors in parentheses. R-squared is pseudo R-squared in Probit regression. *** $\mathrm{p}<0.01, * * \mathrm{p}<0.05, * \mathrm{p}<0.1$ 
Appendix Table A1 Correlation matrix among variables

\begin{tabular}{|c|c|c|c|c|c|c|c|c|}
\hline & risfinass_h $h$ & finedu & finliter & ecofin_search & Risk_tolerance & Gender_male & age & education \\
\hline risfinass_ $h$ & 1.000 & & & & & & & \\
\hline finedu & 0.252 & 1.000 & & & & & & \\
\hline finliter & 0.323 & 0.209 & 1.000 & & & & & \\
\hline ecofin_search & 0.321 & 0.291 & 0.330 & 1.000 & & & & \\
\hline Risk_tolerance & 0.289 & 0.203 & 0.282 & 0.313 & 1.000 & & & \\
\hline Gender_male & -0.026 & 0.021 & 0.022 & 0.122 & 0.089 & 1.000 & & \\
\hline age & -0.175 & -0.136 & -0.281 & -0.148 & -0.350 & 0.073 & 1.000 & \\
\hline education & 0.397 & 0.290 & 0.447 & 0.341 & 0.286 & 0.059 & -0.378 & 1.000 \\
\hline politcstat & 0.144 & 0.149 & 0.134 & 0.162 & 0.050 & 0.140 & 0.118 & 0.267 \\
\hline marriage & -0.032 & -0.071 & -0.016 & 0.005 & -0.055 & 0.048 & 0.039 & -0.026 \\
\hline hukou_agr & -0.311 & -0.166 & -0.282 & -0.192 & -0.097 & 0.112 & -0.047 & -0.453 \\
\hline lnincome & 0.136 & 0.089 & 0.159 & 0.095 & 0.166 & -0.004 & -0.393 & 0.229 \\
\hline fin_job & 0.121 & 0.267 & 0.119 & 0.154 & 0.112 & -0.033 & -0.114 & 0.140 \\
\hline hh_size & -0.105 & -0.062 & -0.087 & -0.056 & 0.005 & 0.044 & -0.085 & -0.129 \\
\hline rural & -0.261 & -0.129 & -0.270 & -0.134 & -0.103 & 0.137 & 0.103 & -0.383 \\
\hline east & 0.167 & 0.052 & 0.095 & 0.036 & 0.035 & -0.013 & -0.021 & 0.149 \\
\hline west & -0.083 & -0.015 & -0.057 & 0.006 & 0.027 & 0.034 & -0.015 & -0.095 \\
\hline
\end{tabular}

Continued Appendix Table A1 Correlation matrix among variables

\begin{tabular}{|c|c|c|c|c|c|c|c|c|c|}
\hline & politcstat & marriage & hukou_agr & lnincome & fin_job & hh_size & rural & east & west \\
\hline politcstat & 1.000 & & & & & & & & \\
\hline marriage & 0.036 & 1.000 & & & & & & & \\
\hline hukou_agr & -0.200 & 0.066 & 1.000 & & & & & & \\
\hline lnincome & -0.005 & 0.085 & 0.012 & 1.000 & & & & & \\
\hline fin_job & 0.038 & -0.032 & -0.080 & 0.092 & 1.000 & & & & \\
\hline hh_size & -0.063 & 0.206 & 0.238 & 0.203 & -0.038 & 1.000 & & & \\
\hline rural & -0.096 & 0.069 & 0.556 & -0.029 & -0.071 & 0.228 & 1.000 & & \\
\hline east & 0.041 & -0.005 & -0.114 & 0.020 & 0.025 & -0.105 & -0.183 & 1.000 & \\
\hline west & -0.018 & -0.005 & 0.072 & -0.017 & -0.012 & 0.068 & 0.084 & -0.555 & 1.000 \\
\hline
\end{tabular}


Appendix Table A2 Row percentages of cross tabulation between age and risky financial asset holding $(\mathrm{N}=32,554)$

\begin{tabular}{ccc|c}
\hline Age group & \multicolumn{2}{c}{ Risky financial asset holding } & Total \\
& 0 & 1 & 100.00 \\
$18-29$ & 65.08 & 34.92 & 100.00 \\
$30-39$ & 73.41 & 26.59 & 100.00 \\
$40-49$ & 83.53 & 16.47 & 100.00 \\
$50-59$ & 87.37 & 12.63 & 100.00 \\
Above 60 & 89.82 & 10.18 & 100.00 \\
\hline Total & 83.73 & 16.27 &
\end{tabular}


Appendix Table A3 Robustness checks by using 2013 CFHS

\begin{tabular}{|c|c|c|c|c|c|}
\hline & $\begin{array}{c}(1) \\
\text { risfinass_h }\end{array}$ & $\begin{array}{l}\text { (2) } \\
\text { Average marginal } \\
\text { effects }\end{array}$ & $\begin{array}{c}\text { (3) } \\
\text { finliter }\end{array}$ & $\begin{array}{c}\text { (4) } \\
\text { risfinass_h }\end{array}$ & $\begin{array}{c}\text { Average marginal } \\
\text { effects }\end{array}$ \\
\hline finedu & $\begin{array}{c}0.331 * * * \\
(0.042)\end{array}$ & $\begin{array}{c}0.047 * * * \\
(0.006)\end{array}$ & $\begin{array}{c}0.276 * * * \\
(0.025)\end{array}$ & $\begin{array}{c}0.285 * * * \\
(0.042)\end{array}$ & $\begin{array}{c}0.040 * * * \\
(0.006)\end{array}$ \\
\hline finliter & & & & $\begin{array}{c}0.221 * * * \\
(0.016)\end{array}$ & $\begin{array}{c}0.031 * * * \\
(0.002)\end{array}$ \\
\hline Gender_male & $\begin{array}{c}-0.085^{* * *} \\
(0.028)\end{array}$ & $\begin{array}{c}-0.012 * * \\
(0.004)\end{array}$ & $\begin{array}{l}-0.021 * \\
(0.011)\end{array}$ & $\begin{array}{c}-0.084 * * * \\
(0.028)\end{array}$ & $\begin{array}{c}-0.012 * * * \\
(0.004)\end{array}$ \\
\hline age & $\begin{array}{c}0.001 \\
(0.001)\end{array}$ & $\begin{array}{c}0.0002 \\
(0.0002)\end{array}$ & $\begin{array}{c}-0.008^{* * *} \\
(0.0004)\end{array}$ & $\begin{array}{c}0.003 * * * \\
(0.001)\end{array}$ & $\begin{array}{c}0.0004 * * * \\
(0.0002)\end{array}$ \\
\hline education & $\begin{array}{c}0.092 * * * \\
(0.005)\end{array}$ & $\begin{array}{c}0.013 * * * \\
(0.001)\end{array}$ & $\begin{array}{c}0.038 * * * \\
(0.002)\end{array}$ & $\begin{array}{c}0.083 * * * \\
(0.005)\end{array}$ & $\begin{array}{c}0.012 * * * \\
(0.001)\end{array}$ \\
\hline politcstat & $\begin{array}{l}0.065^{*} \\
(0.035)\end{array}$ & $\begin{array}{l}0.009^{*} \\
(0.005)\end{array}$ & $\begin{array}{c}0.103 * * * \\
(0.016)\end{array}$ & $\begin{array}{c}0.046 \\
(0.035)\end{array}$ & $\begin{array}{c}0.006 \\
(0.005)\end{array}$ \\
\hline marriage & $\begin{array}{c}0.249 * * * \\
(0.042)\end{array}$ & $\begin{array}{c}0.036 * * * \\
(0.006)\end{array}$ & $\begin{array}{l}0.038 * * \\
(0.015)\end{array}$ & $\begin{array}{c}0.241 * * * \\
(0.042)\end{array}$ & $\begin{array}{c}0.034 * * * \\
(0.006)\end{array}$ \\
\hline hukou_agr & $\begin{array}{c}-0.526^{* * *} \\
(0.037)\end{array}$ & $\begin{array}{c}-0.075^{* * *} \\
(0.005)\end{array}$ & $\begin{array}{c}-0.102 * * * \\
(0.015)\end{array}$ & $\begin{array}{c}-0.518 * * * \\
(0.038)\end{array}$ & $\begin{array}{c}-0.073 * * * \\
(0.005)\end{array}$ \\
\hline lnincome & $\begin{array}{c}0.022 * * * \\
(0.003)\end{array}$ & $\begin{array}{c}0.003 * * * \\
(0.0004)\end{array}$ & $\begin{array}{c}0.006 * * * \\
(0.001)\end{array}$ & $\begin{array}{c}0.021 * * * \\
(0.003)\end{array}$ & $\begin{array}{c}0.003 * * * \\
(0.0004)\end{array}$ \\
\hline fin_job & $\begin{array}{c}0.276^{* * *} \\
(0.095)\end{array}$ & $\begin{array}{c}0.039 * * * \\
(0.014)\end{array}$ & $\begin{array}{c}0.166^{* * *} \\
(0.062)\end{array}$ & $\begin{array}{c}0.257 * * * \\
(0.095)\end{array}$ & $\begin{array}{c}0.036^{* * *} \\
(0.013)\end{array}$ \\
\hline hh_size & $\begin{array}{c}-0.032 * * * \\
(0.012)\end{array}$ & $\begin{array}{c}-0.005^{* * *} \\
(0.002)\end{array}$ & $\begin{array}{c}-0.017 * * * \\
(0.003)\end{array}$ & $\begin{array}{c}-0.027 * * \\
(0.012)\end{array}$ & $\begin{array}{c}-0.004 * * \\
(0.002)\end{array}$ \\
\hline rural & $\begin{array}{c}-0.490 * * * \\
(0.050)\end{array}$ & $\begin{array}{c}-0.070 * * * \\
(0.007)\end{array}$ & $\begin{array}{c}-0.061 * * * \\
(0.013)\end{array}$ & $\begin{array}{c}-0.470 * * * \\
(0.050)\end{array}$ & $\begin{array}{c}-0.066^{* * *} \\
(0.007)\end{array}$ \\
\hline east & $\begin{array}{c}0.393 * * * \\
(0.084)\end{array}$ & $\begin{array}{c}0.056 * * * \\
(0.012)\end{array}$ & $\begin{array}{l}0.064 * \\
(0.038)\end{array}$ & $\begin{array}{c}0.385 * * * \\
(0.084)\end{array}$ & $\begin{array}{c}0.054 * * * \\
(0.012)\end{array}$ \\
\hline west & $\begin{array}{c}-0.312 * * \\
(0.139)\end{array}$ & $\begin{array}{c}-0.044 * * \\
(0.020)\end{array}$ & $\begin{array}{c}0.143 * * * \\
(0.048)\end{array}$ & $\begin{array}{c}-0.333 * * \\
(0.139)\end{array}$ & $\begin{array}{c}-0.047 * * \\
(0.020)\end{array}$ \\
\hline constant & $\begin{array}{c}-2.335^{* * *} \\
(0.128)\end{array}$ & & $\begin{array}{c}0.745 * * * \\
(0.045)\end{array}$ & $\begin{array}{c}-2.522 * * * \\
(0.128)\end{array}$ & \\
\hline Observation & 21,420 & 21,420 & 21,420 & 21,420 & 21,420 \\
\hline R-squared & 0.262 & & 0.169 & 0.273 & \\
\hline Province FE & YES & YES & YES & YES & YES \\
\hline
\end{tabular}

Note: Robust standard errors in parentheses. R-squared is pseudo R-squared in Probit regression. *** $\mathrm{p}<0.01, * * \mathrm{p}<0.05, * \mathrm{p}<0.1$ 
Continued Appendix Table A3 Robustness checks by using 2013 CFHS

\begin{tabular}{|c|c|c|c|c|c|c|}
\hline & ecofin_search & $\begin{array}{c}(7) \\
\text { risfinass_h }\end{array}$ & $\begin{array}{l}\text { (8) } \\
\text { Average marginal } \\
\text { effects }\end{array}$ & $\begin{array}{c}(9) \\
\text { Risk_tolerance }\end{array}$ & $\begin{array}{c}(10) \\
\text { risfinass_h }\end{array}$ & $\begin{array}{l}\text { Average marginal } \\
\text { effects }\end{array}$ \\
\hline finedu & $\begin{array}{c}0.678 * * * \\
(0.030)\end{array}$ & $\begin{array}{c}0.164 * * * \\
(0.042)\end{array}$ & $\begin{array}{c}0.023 * * * \\
(0.006)\end{array}$ & $\begin{array}{c}0.437 * * * \\
(0.033)\end{array}$ & $\begin{array}{c}0.264 * * * \\
(0.042)\end{array}$ & $\begin{array}{c}0.037 * * * \\
(0.006)\end{array}$ \\
\hline ecofin_search & & $\begin{array}{c}0.277 * * * \\
(0.013)\end{array}$ & $\begin{array}{c}0.038 * * * \\
(0.002)\end{array}$ & & & \\
\hline Risk_tolerance & & & & & $\begin{array}{c}0.188 * * * \\
(0.011)\end{array}$ & $\begin{array}{c}0.026 * * * \\
(0.002)\end{array}$ \\
\hline Gender_male & $\begin{array}{c}0.239 * * * \\
(0.015)\end{array}$ & $\begin{array}{c}-0.163^{* * *} \\
(0.029)\end{array}$ & $\begin{array}{c}-0.022 * * * \\
(0.004)\end{array}$ & $\begin{array}{c}0.226 * * * \\
(0.016)\end{array}$ & $\begin{array}{c}-0.139 * * * \\
(0.028)\end{array}$ & $\begin{array}{c}-0.020 * * * \\
(0.004)\end{array}$ \\
\hline age & $\begin{array}{c}-0.005 * * * \\
(0.001)\end{array}$ & $\begin{array}{c}0.002 \\
(0.001)\end{array}$ & $\begin{array}{c}0.0002 \\
(0.0002)\end{array}$ & $\begin{array}{c}-0.024 * * * \\
(0.001)\end{array}$ & $\begin{array}{c}0.006 * * * \\
(0.001)\end{array}$ & $\begin{array}{l}0.001 * * * \\
(0.0002)\end{array}$ \\
\hline education & $\begin{array}{c}0.053 * * * \\
(0.002)\end{array}$ & $\begin{array}{c}0.080 * * * \\
(0.005)\end{array}$ & $\begin{array}{c}0.011 * * * \\
(0.001)\end{array}$ & $\begin{array}{c}0.027 * * * \\
(0.002)\end{array}$ & $\begin{array}{c}0.086 * * * \\
(0.005)\end{array}$ & $\begin{array}{c}0.012 * * * \\
(0.001)\end{array}$ \\
\hline politcstat & $\begin{array}{c}0.206 * * * \\
(0.022)\end{array}$ & $\begin{array}{c}0.030 \\
(0.036)\end{array}$ & $\begin{array}{c}0.004 \\
(0.005)\end{array}$ & $\begin{array}{l}0.045^{*} \\
(0.023)\end{array}$ & $\begin{array}{l}0.068^{*} \\
(0.036)\end{array}$ & $\begin{array}{l}0.009^{*} \\
(0.005)\end{array}$ \\
\hline marriage & $\begin{array}{c}0.159 * * * \\
(0.020)\end{array}$ & $\begin{array}{c}0.227 * * * \\
(0.043)\end{array}$ & $\begin{array}{c}0.031 * * * \\
(0.006)\end{array}$ & $\begin{array}{c}-0.113 * * * \\
(0.022)\end{array}$ & $\begin{array}{c}0.265^{* * * *} \\
(0.043)\end{array}$ & $\begin{array}{c}0.037 * * * \\
(0.006)\end{array}$ \\
\hline hukou_agr & $\begin{array}{c}-0.099 * * * \\
(0.020)\end{array}$ & $\begin{array}{c}-0.525 * * * \\
(0.038)\end{array}$ & $\begin{array}{c}-0.072 * * * \\
(0.005)\end{array}$ & $\begin{array}{c}-0.057 * * * \\
(0.021)\end{array}$ & $\begin{array}{c}-0.524 * * * \\
(0.038)\end{array}$ & $\begin{array}{c}-0.073 * * * \\
(0.005)\end{array}$ \\
\hline lnincome & $\begin{array}{c}0.004 * * \\
(0.002)\end{array}$ & $\begin{array}{c}0.021 * * * \\
(0.003)\end{array}$ & $\begin{array}{c}0.003 * * * \\
(0.0004)\end{array}$ & $\begin{array}{c}0.004 * * \\
(0.002)\end{array}$ & $\begin{array}{c}0.022 * * * \\
(0.003)\end{array}$ & $\begin{array}{c}0.003 * * * \\
(0.0005)\end{array}$ \\
\hline fin_job & $\begin{array}{c}0.479 * * * \\
(0.072)\end{array}$ & $\begin{array}{c}0.145 \\
(0.099)\end{array}$ & $\begin{array}{c}0.020 \\
(0.014)\end{array}$ & $\begin{array}{c}0.261 * * * \\
(0.079)\end{array}$ & $\begin{array}{c}0.240 * * \\
(0.096)\end{array}$ & $\begin{array}{c}0.034 * * \\
(0.013)\end{array}$ \\
\hline hh_size & $\begin{array}{c}-0.012 * * \\
(0.005)\end{array}$ & $\begin{array}{c}-0.029 * * \\
(0.012)\end{array}$ & $\begin{array}{c}-0.004 * * \\
(0.002)\end{array}$ & $\begin{array}{c}0.002 \\
(0.005)\end{array}$ & $\begin{array}{c}-0.029 * * \\
(0.012)\end{array}$ & $\begin{array}{c}-0.004 * * \\
(0.002)\end{array}$ \\
\hline rural & $\begin{array}{c}0.007 \\
(0.019)\end{array}$ & $\begin{array}{c}-0.511 * * * \\
(0.052)\end{array}$ & $\begin{array}{c}-0.070 * * * \\
(0.007)\end{array}$ & $\begin{array}{c}0.030 \\
(0.021)\end{array}$ & $\begin{array}{c}-0.510 * * * \\
(0.051)\end{array}$ & $\begin{array}{c}-0.071 * * * \\
(0.007)\end{array}$ \\
\hline east & $\begin{array}{c}-0.118^{* *} \\
(0.050)\end{array}$ & $\begin{array}{c}0.451 * * * \\
(0.087)\end{array}$ & $\begin{array}{c}0.062^{* * *} \\
(0.012)\end{array}$ & $\begin{array}{c}-0.189 * * * \\
(0.056)\end{array}$ & $\begin{array}{c}0.436 * * * \\
(0.087)\end{array}$ & $\begin{array}{c}0.061 * * * \\
(0.012)\end{array}$ \\
\hline west & $\begin{array}{c}0.355 * * * \\
(0.066)\end{array}$ & $\begin{array}{c}-0.379 * * * \\
(0.144)\end{array}$ & $\begin{array}{c}-0.052 * * * \\
(0.020)\end{array}$ & $\begin{array}{l}-0.099 \\
(0.067)\end{array}$ & $\begin{array}{c}-0.297 * * \\
(0.142)\end{array}$ & $\begin{array}{c}-0.042 * * \\
(0.020)\end{array}$ \\
\hline constant & $\begin{array}{c}1.663 * * * \\
(0.064)\end{array}$ & $\begin{array}{c}-2.843 * * * \\
(0.135)\end{array}$ & & $\begin{array}{c}2.945 * * * \\
(0.071)\end{array}$ & $\begin{array}{c}-2.93 * * * \\
(0.137)\end{array}$ & \\
\hline Observation & 21,420 & 21,420 & 21,420 & 21,420 & 21,420 & 21,420 \\
\hline R-squared & 0.173 & 0.292 & & 0.152 & 0.279 & \\
\hline Province FE & YES & YES & YES & YES & YES & YES \\
\hline
\end{tabular}

Note: Robust standard errors in parentheses. R-squared is pseudo R-squared in Probit regression. *** $\mathrm{p}<0.01, * * \mathrm{p}<0.05, * \mathrm{p}<0.1$ 
Appendix Table A4 Other robustness checks

(1)

(2)

risfinass_h Average marginal
(3)

(4)

(5)

(6)

stock_h Average marginal fund_h Average marginal effects

\begin{tabular}{|c|c|c|c|c|c|c|}
\hline \multirow[t]{2}{*}{ finedu } & $0.454 * * *$ & $0.084 * * *$ & $0.394 * * *$ & $0.049 * * *$ & $0.315^{* * *}$ & $0.021 * * *$ \\
\hline & $(0.033)$ & $(0.006)$ & $(0.035)$ & $(0.004)$ & $(0.042)$ & $(0.003)$ \\
\hline \multirow[t]{2}{*}{ Gender_male } & -0.029 & -0.005 & 0.036 & 0.005 & $-0.124 * * *$ & $-0.008 * * *$ \\
\hline & $(0.020)$ & $(0.004)$ & $(0.024)$ & $(0.030)$ & $(0.030)$ & $(0.002)$ \\
\hline \multirow[t]{2}{*}{ age } & $-0.001 * * *$ & $-0.002 * * *$ & $-0.003 * * *$ & $-0.0004 * * *$ & 0.001 & 0.0001 \\
\hline & $(0.001)$ & $(0.0002)$ & $(0.001)$ & $(0.0001)$ & $(0.001)$ & $(0.0001)$ \\
\hline \multirow[t]{2}{*}{ education } & $0.111 * * *$ & $0.020 * * *$ & $0.103 * * *$ & $0.013 * * *$ & $0.089 * * *$ & $0.006^{* * *}$ \\
\hline & $(0.004)$ & $(0.001)$ & $(0.004)$ & $(0.001)$ & $(0.006)$ & $(0.0004)$ \\
\hline \multirow[t]{2}{*}{ politcstat } & $0.099 * * *$ & $0.018 * * *$ & 0.035 & 0.004 & $0.081 * *$ & $0.006 * *$ \\
\hline & $(0.026)$ & $(0.005)$ & $(0.029)$ & $(0.004)$ & $(0.036)$ & $(0.002)$ \\
\hline \multirow[t]{2}{*}{ marriage } & $0.111^{* * *}$ & $0.020 * * *$ & $0.027 * * *$ & $0.034 * * *$ & $0.142 * * *$ & $0.010 * * *$ \\
\hline & $(0.029)$ & $(0.005)$ & $(0.036)$ & $(0.004)$ & $(0.045)$ & $(0.003)$ \\
\hline \multirow[t]{2}{*}{ hukou_agr } & $-0.467 * * *$ & $-0.086^{* * *}$ & $-0.595 * * *$ & $-0.075^{* * *}$ & $-0.352 * * *$ & $-0.024 * * *$ \\
\hline & $(0.025)$ & $(0.005)$ & $(0.033)$ & $(0.004)$ & $(0.044)$ & $(0.003)$ \\
\hline \multirow[t]{2}{*}{ lnincome } & $0.016^{* * *}$ & $0.003 * * *$ & $0.018 * * *$ & $0.023 * * *$ & $0.011 * * *$ & $0.001 * * *$ \\
\hline & $(0.002)$ & $(0.0004)$ & $(0.003)$ & $(0.0004)$ & $(0.004)$ & $(0.0002)$ \\
\hline \multirow[t]{2}{*}{ fin_job } & $0.154 * *$ & $0.028 * *$ & -0.030 & -0.004 & $0.167 * *$ & $0.011 * *$ \\
\hline & $(0.069)$ & $(0.013)$ & $(0.073)$ & $(0.009)$ & $(0.081)$ & $(0.005)$ \\
\hline \multirow[t]{2}{*}{ hh_size } & $-0.028 * * *$ & $-0.005 * * *$ & $-0.024 * * *$ & $-0.003 * * *$ & -0.004 & -0.0003 \\
\hline & $(0.066)$ & $(0.001)$ & $(0.008)$ & $(0.001)$ & $(0.002)$ & $(0.001)$ \\
\hline \multirow[t]{2}{*}{ rural } & $-0.531 * * *$ & $-0.098 * * *$ & $-0.597 * * *$ & $-0.075^{* * *}$ & $-0.531 * * *$ & $-0.036 * * *$ \\
\hline & $(0.037)$ & $(0.007)$ & $(0.057)$ & $(0.007)$ & $(0.077)$ & $(0.005)$ \\
\hline \multirow[t]{2}{*}{ east } & $0.210 * * *$ & $0.039 * * *$ & -0.012 & -0.001 & $0.536 * * *$ & $0.036^{* * *}$ \\
\hline & $(0.065)$ & $(0.012)$ & $(0.074)$ & $(0.009)$ & $(0.109)$ & $(0.007)$ \\
\hline \multirow[t]{2}{*}{ west } & $-0.177 *$ & $-0.033 *$ & $-0.466^{* * *}$ & $-0.059 * * *$ & 0.268 & 0.018 \\
\hline & $(0.106)$ & $(0.019)$ & $(0.141)$ & $(0.177)$ & $(0.169)$ & $(0.011)$ \\
\hline \multirow[t]{2}{*}{ constant } & $-1.636 * * *$ & & $-2.352 * * *$ & & $-3.176^{* * *}$ & \\
\hline & $(0.093)$ & & $(0.110)$ & & $(0.158)$ & \\
\hline Observation & 32,554 & 32,554 & 32,554 & 32,554 & 32,554 & 32,554 \\
\hline R-squared & 0.285 & & 0.272 & & 0.189 & \\
\hline Province FE & YES & YES & YES & YES & YES & \\
\hline
\end{tabular}

Note: Robust standard errors in parentheses. R-squared is pseudo R-squared in Probit regression. $\mathrm{p}<0.01, * * \mathrm{p}<0.05, * \mathrm{p}<0.1$ 
Continued Appendix Table A4 Other robustness checks

\begin{tabular}{|c|c|c|c|c|}
\hline & $\begin{array}{c}(7) \\
\text { wealth management } \\
\text { products_h }\end{array}$ & $\begin{array}{l}\text { (8) } \\
\text { Average marginal } \\
\text { effects }\end{array}$ & $\begin{array}{c}(9) \\
\text { bond_h }\end{array}$ & $\begin{array}{l}\text { (10) } \\
\text { Average marginal } \\
\text { effects }\end{array}$ \\
\hline finedu & $\begin{array}{c}0.262 * * * \\
(0.035)\end{array}$ & $\begin{array}{c}0.036^{* * *} \\
(0.005)\end{array}$ & $\begin{array}{c}0.425^{* *} \\
(0.200)\end{array}$ & $\begin{array}{l}0.013 * \\
(0.001)\end{array}$ \\
\hline Gender_male & $\begin{array}{c}-0.0638^{* * *} \\
(0.023)\end{array}$ & $\begin{array}{c}-0.009 * * * \\
(0.003)\end{array}$ & $\begin{array}{l}0.271 \\
(0.17)\end{array}$ & $\begin{array}{c}0.001 \\
(0.001)\end{array}$ \\
\hline age & $\begin{array}{c}-0.011^{* * * *} \\
(0.001)\end{array}$ & $\begin{array}{c}-0.002^{* * *} \\
(0.0001)\end{array}$ & $\begin{array}{l}-0.006 \\
(0.006)\end{array}$ & $\begin{array}{l}-0.00001 \\
(0.00001)\end{array}$ \\
\hline education & $\begin{array}{c}0.092^{* * *} \\
(0.004)\end{array}$ & $\begin{array}{c}0.012 * * * \\
(0.001)\end{array}$ & $\begin{array}{c}0.033 \\
(0.030)\end{array}$ & $\begin{array}{c}0.0001 \\
(0.0001)\end{array}$ \\
\hline politcstat & $\begin{array}{c}0.132 * * * \\
(0.029)\end{array}$ & $\begin{array}{c}0.018^{* * *} \\
(0.004)\end{array}$ & $\begin{array}{l}-0.113 \\
(0.217)\end{array}$ & $\begin{array}{r}-0.0003 \\
(0.001)\end{array}$ \\
\hline marriage & $\begin{array}{l}-0.035 \\
(0.031)\end{array}$ & $\begin{array}{l}-0.005 \\
(0.004)\end{array}$ & $\begin{array}{c}0.392 \\
(0.261)\end{array}$ & $\begin{array}{c}0.001 \\
(0.001)\end{array}$ \\
\hline hukou_agr & $\begin{array}{c}-0.259 * * * \\
(0.029)\end{array}$ & $\begin{array}{c}-0.035^{* * *} \\
(0.004)\end{array}$ & $\begin{array}{l}-0.290 * \\
(0.173)\end{array}$ & $\begin{array}{l}-0.001 \\
(0.001)\end{array}$ \\
\hline lnincome & $\begin{array}{c}0.012 * * * \\
(0.003)\end{array}$ & $\begin{array}{c}0.002 * * * \\
(0.0003)\end{array}$ & $\begin{array}{l}-0.0002 \\
(0.018)\end{array}$ & $\begin{array}{l}7.30 \mathrm{e}-07 \\
(0.0001)\end{array}$ \\
\hline fin_job & $\begin{array}{c}0.081 \\
(0.069)\end{array}$ & $\begin{array}{c}0.011 \\
(0.009)\end{array}$ & & \\
\hline hh_size & $\begin{array}{c}-0.028^{* * *} \\
(0.076)\end{array}$ & $\begin{array}{c}-0.004^{* * *} \\
(0.001)\end{array}$ & $\begin{array}{l}-0.001 \\
(0.047)\end{array}$ & $\begin{array}{c}-1.92 \mathrm{e}-06 \\
(0.0001)\end{array}$ \\
\hline rural & $\begin{array}{c}-0.464 * * * \\
(0.043)\end{array}$ & $\begin{array}{c}-0.063^{* * *} \\
(0.006)\end{array}$ & $\begin{array}{l}-0.073 \\
(0.317)\end{array}$ & $\begin{array}{l}-0.0002 \\
(0.001)\end{array}$ \\
\hline east & $\begin{array}{c}0.375 * * * \\
(0.076)\end{array}$ & $\begin{array}{c}0.051 * * * \\
(0.010)\end{array}$ & $\begin{array}{l}-0.122 \\
(0.409)\end{array}$ & $\begin{array}{l}-0.0004 \\
(0.001)\end{array}$ \\
\hline west & $\begin{array}{l}-0.121 \\
(0.119)\end{array}$ & $\begin{array}{l}-0.002 \\
(0.016)\end{array}$ & $\begin{array}{c}0.222 \\
(0.422)\end{array}$ & $\begin{array}{c}0.001 \\
(0.001)\end{array}$ \\
\hline constant & $\begin{array}{c}-1.753^{* * *} \\
(0.109)\end{array}$ & & $\begin{array}{c}-3.724 * * * \\
(0.710)\end{array}$ & \\
\hline $\begin{array}{l}\text { Observation } \\
\text { R-squared }\end{array}$ & $\begin{array}{c}32,554 \\
0.219\end{array}$ & 32,554 & $\begin{array}{c}13,576 \\
0.098\end{array}$ & 13,576 \\
\hline Province FE & YES & YES & YES & YES \\
\hline
\end{tabular}

Note: Robust standard errors in parentheses. R-squared is pseudo R-squared in Probit regression. *** $\mathrm{p}<0.01,{ }^{* *} \mathrm{p}<0.05,{ }^{*} \mathrm{p}<0.1$ 


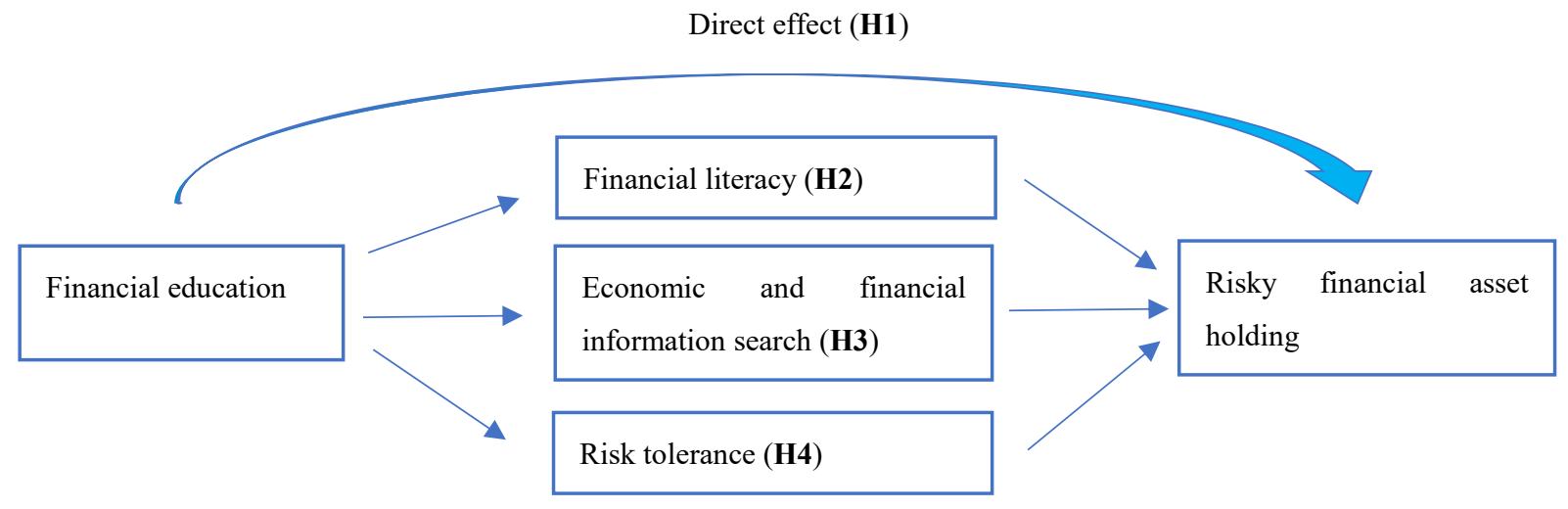

Figure 1. The relationship between financial education and risky financial asset holding 